IZA DP No. 6990

Where Do New Ph.D. Economists Go?

Evidence from Recent Initial Job Placements

Jihui Chen

Qihong Liu

Sherrilyn Billger

November 2012 


\title{
Where Do New Ph.D. Economists Go? Evidence from Recent Initial Job Placements
}

\author{
Jihui Chen \\ Illinois State University \\ Qihong Liu \\ University of Oklahoma \\ Sherrilyn Billger \\ Illinois State University \\ and IZA
}

\section{Discussion Paper No. 6990 \\ November 2012}

\author{
IZA \\ P.O. Box 7240 \\ 53072 Bonn \\ Germany \\ Phone: +49-228-3894-0 \\ Fax: +49-228-3894-180 \\ E-mail: iza@iza.org
}

\begin{abstract}
Any opinions expressed here are those of the author(s) and not those of IZA. Research published in this series may include views on policy, but the institute itself takes no institutional policy positions. The IZA research network is committed to the IZA Guiding Principles of Research Integrity.

The Institute for the Study of Labor (IZA) in Bonn is a local and virtual international research center and a place of communication between science, politics and business. IZA is an independent nonprofit organization supported by Deutsche Post Foundation. The center is associated with the University of Bonn and offers a stimulating research environment through its international network, workshops and conferences, data service, project support, research visits and doctoral program. IZA engages in (i) original and internationally competitive research in all fields of labor economics, (ii) development of policy concepts, and (iii) dissemination of research results and concepts to the interested public.
\end{abstract}

IZA Discussion Papers often represent preliminary work and are circulated to encourage discussion. Citation of such a paper should account for its provisional character. A revised version may be available directly from the author. 
IZA Discussion Paper No. 6990

November 2012

\section{ABSTRACT}

\section{Where Do New Ph.D. Economists Go? Evidence from Recent Initial Job Placements*}

We use data from the 2007-2008 Ph.D. economist job market to investigate initial job placement in terms of job location, job type, and job rank. Our results suggest gender differences in all three dimensions of job placement. Relative to their male counterparts, female candidates are less (more) likely to be placed into academic (government or private sector) jobs and, on average, are placed into worse ranked jobs. Foreign female candidates are also more likely than foreign males to stay in the U.S. When foreign students are placed outside the U.S., they are more likely to be in academia than in government or private sector, while the opposite holds when foreign students are placed in the U.S., which is largely consistent with a stylized theory model. Our results also reveal various country/region heterogeneities in the type, location, and rank of job placements.

JEL Classification: $\quad$ A11, A23, J44

Keywords: Ph.D. labor market, job type, job location, job rank

Corresponding author:

Sherrilyn M. Billger

Department of Economics

Illinois State University

Normal, IL 61790

USA

E-mail: smbillg@ilstu.edu

\footnotetext{
* We thank Leah Brooks, Greg Burge, Jen Graves, John Ham, Cory Koedel, Catherine Mooney, Rati Ram, Adam Rennhoff, and session participants at the 2008 Southern Economic Association Annual Conference and Illinois State University Applied Econometrics Workshop participants for helpful comments and suggestions. We also thank Meredith Willinger, Yoonho Choi, Chris Denly, Hojin Jung, and Golaleh Moshrefi for their excellent research assistance, and University of Oklahoma Honors Research Assistant Program for financial support. Finally, we would like to thank placement coordinators and other individuals at various institutions who exchanged correspondences with us during the course of this project. The usual caveat applies.
} 


\section{Introduction}

The extensive literature on the economist labor market focuses on initial placement or job conditions across all tenure lengths. ${ }^{1}$ These studies show that job outcomes vary with demographic characteristics (e.g., gender and nationality), academic characteristics (e.g., grades, GRE scores, advisor reputation, and research portfolio), and program characteristics (e.g., the rank and size of a doctoral program). Our paper is similar to the existing literature in that we investigate the relationship between job placement and various individual and program characteristics. On the other hand, our paper differs from existing studies in several ways.

First, due to the labor-intensive data collection process, existing studies usually focus on a handful of top-ranked programs or use data collected from the AEA Membership directory or surveys with low response rates. ${ }^{2}$ In recent years, the information on job candidates and placement outcomes has become more accessible to researchers, as many programs advertise their candidates and placements on the internet. We have therefore compiled a comprehensive sample of 578 candidates from 57 top economics programs in the $2007-2008$ job market, ${ }^{3}$ allowing us to conduct an analysis generally free of selection bias.

Second, in addition to gender (which is extensively studied in the literature), we explore source country heterogeneity in job placement outcomes. Existing studies usually use a single country dummy (i.e., the U.S.) as a demographic characteristic, with a few exceptions (Krueger and Wu, 2000; Grove, Dutkowsky and Grodner, 2007) who use a combination of country and continent dummies. Our analysis provides a more careful exploration across many countries.

Third, few existing studies are concerned with whether the candidate is placed within or outside the U.S. Instead, studies analyzing job location usually consider regions within the U.S. The American labor market has become more saturated in recent years, partially fueled by a weak economy. This saturation, coupled with the increased prestige of many international universities, has led a number of Ph.D.s (particularly foreign-born) to pursue employment outside the U.S. Anecdotal evidence reveals this trend. For example, Siegfried and Stock (2004) document that the percentage of foreign candidates has been increasing over time, from about $33 \%$ in the 1976-1977 cohort to $62 \%$ in the 2000-2001 cohort. They also report the percentage of U.S. placements but they include the U.S. candidates while we only consider foreign candidates in the job location analysis. This is also seen in our data, where about $71 \%$ (409 out of 578) of the candidates are foreigners and $37 \%$ (146 out of 395) of those who succeed in initial job placements are placed outside the U.S. Therefore,

\footnotetext{
${ }^{1}$ Coupe (2004) and Ehrenberg (2004) provide excellent surveys of this literature. There are also studies focusing on the success of completing the Economics Ph.D. (Siegfried and Stock 2001; Stock and Siegfried 2006a; Grove, Dutkowsky and Grodner 2007).

${ }^{2}$ For example, Krueger and Wu (2000), Oyer (2006), Athey et al. (2007), and Grove and Wu (2007) use a handful of top programs. McMillen and Singell (1994) and McDowell, Singell and Ziliak (1999, 2001) use AEA membership directory data. Most other studies use survey data, including Barbezat (1992), Neumark and Gardecki (1998), Siegfried and Stock (1999, 2004), Stock and Siegfried (2001), and Gallet et al. (2005).

${ }^{3}$ Source: http://consusrankings.com/2008/04/28/us-news-best-graduate-economics-programs-2005/.
} 
it is increasingly important to document the patterns of job placements in terms of geographic location. The significance of this is twofold. First, it measures supply in the labor market of U.S. and foreign economists. Second, a candidate's investment in human capital should adjust to better match their future job location. Currently, the prominent job search manuals (e.g., Cawley, 2011) are almost exclusively based on the U.S. market, but it appears that the global market may be considered. To more carefully explore this phenomenon, we also offer a stylized theory model to link job type and job location.

In this study, we pose the following research question: where do new Ph.D. economists go? In particular, we examine three important elements of initial job placements: job location (within or outside the U.S.), job type (academia, government, or private sector) and job rank.

Our results reveal significant gender differences and source country heterogeneity in job location. Among foreign candidates, females are more likely to remain in the U.S. relative to their male counterparts. In the job location analysis, we introduce a set of country/region dummies to account for the considerable country/region disparities arising in the sample (more details can be found in Section 5.1). For example, ceteris paribus, candidates from Argentina and India are most likely to work in the U.S. upon graduation, while Korean students are the least likely to stay.

In addition, we show evidence of gender difference in the placement outcomes. ${ }^{4}$ For example, in our baseline model, we find that females are $7.6 \%$ less likely to be placed into academic jobs relative to male candidates. On the other hand, female candidates are more likely to be placed into government jobs $(2 \%)$ and private sector jobs (5.4\%), but these gender differences are insignificant. Our findings are in line with previous studies (e.g., McDowell, Singell and Ziliak, 1999, 2001; Broder, 1993) which show that gender difference has diminished over time. Our results also indicate that female candidates' placements are on average almost 9 ranks worse relative to male candidates in our baseline model, but this difference is insignificant. ${ }^{5}$ Our results further reveal significant country/region heterogeneity in both job type and job rank. We also find significant gender differences in job rank for candidates from selected countries.

Finally, to offer some theoretical considerations for the main results, we develop a stylized model to link job type and job location. Focusing on foreign candidates, we divide all permanent jobs into two categories: academic and non-academic (i.e., government and private sector jobs are combined), to be consistent with the theoretical model. In foreign job markets, non-academic employers have a relatively large pool of local labor supply, but academic jobs rely more on U.S.-educated Ph.D. economists. Under this assumption, candidates would face less (more) competition in academia

\footnotetext{
${ }^{4}$ Note that this gender difference does not necessarily reveal gender discrimination. For example, Barbezat (1992) documents significant gender differences in their preferences for jobs types. On the other hand, McMillen and Singell (1994) find no significant gender difference in sector choice probabilities (employee preference), but the marginal effect of several productive attributes is smaller for women than for men (employer discrimination).

${ }^{5}$ Our job rank analysis follows Krueger and Wu (2000) closely. Other studies have adopted more crude measure of job rank to compare gender differences. For example, McMillen and Singell (1994) divide placements into top 50 economics department and other departments. Barbezat (1992) divide employment into top 15, 16-30, and other economics departments, respectively.
} 
(nonacademia) in the foreign job market than in the U.S. market. Thus, we expect to see that, for foreign candidates, foreign placements are more likely to be academic than U.S. placements. This is confirmed in our empirical results where we find that U.S. placements are less likely to be academic than foreign placements, by $2.7 \%-7.5 \%$ depending on the model specification. This correlation becomes significant and much stronger (7\%-13.4\%) when Korean candidates are excluded. We see that those who stay in the U.S. are much more likely not to take academic jobs. ${ }^{6}$

The remainder of the paper is organized as follows. Section 2 offers a review of the related literature. We discuss our data in Section 3 and provide descriptive statistics results in Section 4. Section 5 contains the main estimation results on job type, job location and job rank as well as a stylized theory linking job type and job location. We conclude in Section 6. A list of variables and proof of Proposition 1 are provided in Appendix A.1 and A.2, respectively.

\section{Literature review}

Our paper is most closely related to studies on initial job placement of new $\mathrm{Ph}$.D. economists (Siegfried and Stock 1999, 2004; Stock and Siegfried 2001, 2006). Several studies analyze the type of initial job placements and/or starting salary. Barbezat (1992) is among the first to study the labor market for new economists. She surveys about 600 candidates (with 291 usable responses) in the top 46 Economics programs in the 1988-1989 market. Her data set consists of both CVs and questionnaires. In particular, her survey includes candidates' preferences across different job types which she uses together with other individual and program characteristics to predict candidates' job types. While our analysis also relies on candidates' CVs, much has changed since the Barbezat study, allowing us to offer an updated understanding of recent doctoral education outcomes. Siegfried and Stock (1999) conduct an interesting survey of economics Ph.D. graduates to explore initial job placement and job satisfaction, highlighting differences across employment sector. They document different placement rates among various sub-fields and background characteristics, such as whether the candidate completed a master's degree prior to starting a Ph.D. program (we also include this variable in our analysis). Stock and Siegfried (2001) survey the 1996-1997 cohort of Ph.D. economists and investigate job type and salary. In an updated version, Siegfried and Stock (2004) provide an array of summary statistics as a snap-shot of the 2001-2002 graduating class. They highlight the influx of international workers, salary differences across sectors, and job satisfaction distributions by sector and Ph.D. program ranking. McMillen and Singell (2001) use the AEA Membership Directory and focus on the role of gender in job search. They conduct the analysis using subsamples of each gender, and conclude that pre-market differences in attributes do not fully explain the post-market gender discrepancies in job placement. Their findings of gender differences could stem from either the employer side (discrimination) or the candidate side (candidates'

\footnotetext{
${ }^{6}$ More details are provided in Section 5.3.2 where we also offer an explanation of why the Korean candidates stand in sharp contrast with others in terms of the relationship between job type and job location.
} 
preferences). ${ }^{7}$

Other studies are concerned with mentorship configurations in terms of gender and their impact on job placement outcome. For example, Neumark and Gardecki (1998) survey various programs for their female graduate students. They find that neither the number of female faculty in the department nor the gender of dissertation chair affects the quality of female students' first job placement. Hilmer and Hilmer (2007) extend this analysis by including male graduate students and analyzing research productivity during the doctoral program, in addition to placement quality. They find that female students working with male advisors are more likely to accept researchoriented jobs than male students with male advisors upon graduation.

Aside from initial job placements, intermediate job search outcomes are also analyzed in this literature. Stock and Alston (2000) include both new and previous Ph.D.s in the 1995-1996 market and investigate the impact of various individual and program characteristics on the number of interviews a candidate receives and the probability of receiving at least one offer. Gallet, List and Orazem (2005) compare employers' and candidates' search strategies between boom (i.e., 1987) and bust (i.e., 1997) job markets. Using survey data of two cohorts (boom and bust), they confirm that in weak job markets, academic employers raise their hiring standards, candidates from top programs are more likely to apply for lower-ranked academic positions while those from low programs are more likely to apply for nonacademic positions.

Another strand of the literature analyzes later career outcomes, not just the initial job placement. Much of the focus is on gender gap. ${ }^{8}$ Kahn (1995) reports statistics on female economists from various aspects such as grades, Ph.D. admission and graduation, job placement, publications and salary. McDowell, Singell and Ziliak $(1999,2001)$ use panel data of AEA members in 4 selected years between 1960 and 1990. They document evidence of a glass ceiling for women in economics; women are less likely to be promoted, or are promoted more slowly than men, after controlling for research productivity, life-cycle attributes and fields of specialization. However, this gender difference is diminishing over time. ${ }^{9}$ Gender differences in promotion also exist in other academic markets. Ginther and Hayes (2003) identify significant gender differences in promotion for humanities professors which are responsible for the gender differences in salary. ${ }^{10}$ In contrast, Blackaby and Frank (2000) and Blackaby, Booth and Frank (2005) find both gender difference in promotions and within-rank gender pay gaps. Their UK survey data include outside offers, which they argue explain the gender differences in pay and promotion. In another study, Kolpin and Singell (1996)

\footnotetext{
${ }^{7}$ Results in Barbezat (1992) Table 6 indicates significant gender differences in how they value certain workplace characteristics.

${ }^{8}$ Some studies focus on race, in particular, the status of minorities in the Economics profession. See, for example, Collins (2000).

${ }^{9}$ This is in the same spirit as Broder (1993), who uses data on grants and grant applications of the NSF Economics program and finds significant gender difference in older cohorts but not at the assistant professor level, both in terms of salary and other job characteristics.

${ }^{10}$ In a recent paper, Krause, Rinne and Zimmermann (2012) conduct a randomized experiment among applicants to a research institution and analyze the impacts of anonymous job applications on interview invitations.
} 
investigate gender difference in initial job placements and its subsequent impacts on departmental research productivity. Using data on economists in 4 years between 1970s and 1980s, they find that higher-ranked departments are less likely to hire females, despite the fact that women in 1970s cohort were more productive than their male counterparts at comparable institutions. Moreover, departments hiring fewer women in 1970s subsequently declined in publications rank relative to other departments, suggesting that employment discrimination is costly to the employer.

Other studies investigate the determinants of placement quality. Using a sample consisting of 1,029 graduate students who enrolled in the top five economics programs in the 1990s, Athey et al. (2007) find that, conditional on first-year grades, neither demographic characteristics, nor GRE scores, nor an additional master's degree seems to affect the quality of job placement. Using data on applicants to a top 5 Economics program in 3 selected years, Krueger and Wu (2000) examine the relationship between admission to graduate program and the subsequent outcome of job placement, and argue that subjective ratings of admission committee and objective GRE scores are effective signals of professional success. Still other studies analyze the determinants of research productivity. Buchmueller, Dominitz and Hansen (1999) use the AEA COGEE survey and regress research productivity on initial job placement (rank and type) and pre-market individual and program characteristics. Oyer (2006) finds that better initial placements lead to greater professional productivity in the long run. Grove and Wu (2007) identify both subjective and objective selection criteria in top-five economics doctoral programs. Their main contributions include the use of the identity of letter writers and admission committee ranking as effective signals of economics talent. They conclude that superior math skills (e.g., quantitative GRE scores) and the prominence of letter writers are highly correlated with applicants' subsequent success in doctoral program and future academic career.

\section{Data}

To capture most candidates on the Ph.D. economist job market, we include 57 top U.S. economics programs in our sample. ${ }^{11}$ Due to the nature of the job search process, our data collection involved two steps. First, in November 2007, we obtained a total of 617 candidates' CVs from each program's placement web page. ${ }^{12}$ From these CVs, we extracted the candidate and program characteristics variables, which are described in Appendix A.1. The second step started in fall 2008 when we collected candidates' placement information.

Focusing on initial job placements in the 2007-2008 market, we employ two criteria during this two-step process: (1) it should be the candidate's first time on the job market, and (2) it should be

\footnotetext{
${ }^{11}$ We selected 57 of the top graduate economics programs based on the US News 2005 ranking. We include economics programs in business schools as well.

${ }^{12}$ It is possible that a listed job market candidate may later choose not to proceed and stay in the program one more year. Our data seem to confirm this possibility. It is also possible but less likely that a late candidate may enter into the market after mid-November for jobs starting the following year.
} 
his/her first job placement. Some programs list the placement outcomes online. For the remaining candidates, we conducted extensive online searches through which the placement outcomes for most candidates placement outcomes were confirmed. In cases where the internet search failed, we directly contacted their program placement directors/coordinators, advisors, faculty members and sometimes other students in the same department for a definitive answer. We were able to confirm all placement outcomes in our final sample.

Our final sample includes a total of 578 candidates. While this is not an exhaustive list of all the job candidates in the year 2007-08, the sample is representative of candidates (including both new Ph.D.s and ABDs) who participated in the initial job search, since 57 of the top programs are included. That particular job market may be considered as successful overall in that only 19 candidates were not placed as of fall 2008. More details are provided in Section 4.

\section{Descriptive analysis}

Our data include the following information for each candidate: (1) demographic information including gender and citizenship; (2) academic information including characteristics of the candidate's Ph.D. program and advisor(s), whether s/he has a previous master's degree, teaching awards or had journal publication or revise and resubmit; and (3) placement information including whether the candidate is placed successfully and if yes, the type, location and rank of job placement. Now we turn to descriptive statistics of each category. Refer to Appendix A.1 for variable definitions.

\section{Demographic characteristics}

Table 1 lists the gender composition of the sample. About 1/3 of the candidates $(199 / 578)$ are female and this ratio is roughly the same across program tiers. Figure 1 indicates the female ratio by country/region. Taiwan has the highest female ratio (61\%) among Asian nations with more than 10 students, followed by China (61\%) and India (52\%). Of the European countries with over 10 students, Italy has the highest ratio of female students (55\%) followed by Russia (30\%). A few Latin American countries also have high female ratios, such as Colombia and Venezuela.

$$
<<\text { Figure } 1 \text { here }>>
$$

We also compare the ratios of international candidates between doctoral programs and initial job placements. In Table 1, the fraction of foreign students is inversely U-shaped in program ranking, with Tier 1 and Tier 4 admitting a relatively lower percentage of foreign students than the middle tiers (tier 2 and 3 ) do.

\footnotetext{
$<<$ Table 1 here $>>$
} 


\section{Academic characteristics}

Table 2 reports the summary statistics for academic characteristics. All variables except size are dummy variables. About half of the candidates have a master's degree prior to entering the doctoral program. As expected, only $4 \%$ of the candidates have a top advisor or co-advisor. $1 \%$ of the candidates have either a journal publication or revise and resubmit (R\&R) at the top four economics journals, and the fraction rises slightly for those who have either a publication or $\mathrm{R} \& \mathrm{R}$ at the economics journals ranked top 5 through 50 (5\% and 3\%, respectively). In the sample, about $26 \%$ of the candidates earned at least one teaching award. Finally, the average program size, defined as the number of candidates on the job market, ranges between 1 and 32 .

$$
<<\text { Table } 2 \text { here }>>
$$

\section{$\underline{\text { Placement characteristics }}$}

Stayus is defined as the candidate accepts a job in the U.S. while Return refers to the case where the candidate accepts a job in his/her home continent. ${ }^{13}$ As almost all U.S. students take a job in the U.S., we thus exclude American students when reporting the results in Table 3, as well as those who fail to find a job, leaving us a subsample of 395 students.

$$
<<\text { Table } 3 \text { here }>>
$$

Table 3 reports the fraction of students staying and the fraction returning, separated by gender, program tier, and continent respectively. Foreign students usually either stay in the U.S. or return to home continent/country, so we expect opposite trends between the stay and return ratios. About $63 \%$ of foreign students accepted jobs in the U.S., and this ratio varies slightly across gender (female $69 \%$ vs. male $60 \%$ ) and program ranking (tiers 1 and 4 slightly higher than tiers 2 and 3 ). Approximately $23 \%$ of foreign female candidates return to their home continents, compared to $31 \%$ for foreign male students, while the return ratios are higher for tiers 2 and 3 than for the other two tiers.

When broken down by continents, we find that Middle East has the highest ratio of staying in the U.S., or $81 \%$, with other continents in the vicinity of $60 \%$, except for Africa. In terms of return-to-home-continent ratios, Mideast, Latin America, and Africa rank the lowest three, in such order. Figures 2 and 3 show the distribution of these ratios by country. Darker color indicates the higher stay/return ratio. Among countries with at least 20 candidates, South Korea has the lowest stay ratio (38\%), followed by Russia (43\%), China (61\%), Turkey (72\%) and India (74\%).

$$
\begin{aligned}
& <<\text { Figure } 2 \text { here }>> \\
& <<\text { Figure } 3 \text { here }>>
\end{aligned}
$$

\footnotetext{
${ }^{13}$ These two outcomes coincide with each other for U.S. candidates. For candidates from other continents, they are not perfectly correlated since a foreign student can be placed into a country outside U.S. and his/her home continent.
} 
Table 4 reports the types of the initial jobs taken by the Ph.D.s in our sample. Note that we now include U.S. candidates. As one would expect, a considerable number of students (309 or about $55 \%$ ) were placed into (tenure-track) academic positions, followed by the private sector (125 or about 22\%). 14\% of candidates found government jobs (e.g., Federal Agencies and regional central banks) and the remaining 48 candidates (9\%) found temporary jobs (e.g., postdoc and visiting positions). Across gender, female candidates are less likely than males to be placed into academic jobs ( $49 \%$ vs. $59 \%)$ and the result is reversed for the private sector (27\% vs. $20 \%)$. There is little difference across program tiers, but more prominent differences exist across continents.

$$
<<\text { Table } 4 \text { here }>>
$$

\section{Estimation results}

In the previous section, we discuss descriptive statistics on the composition of candidates by home nation/continent, gender, program ranking, and their placement in terms of location (stay or return) and type. Next, we present a variety of regression results to explore how various candidate characteristics affect their placement outcomes.

\subsection{Job location}

The U.S. job market for economists is obviously impacted by the health of the overall economy. Decades ago, we might have expected most international students to try to stay in the U.S., but that is no longer obvious. Some other economies (e.g. China) have been booming and job candidates are increasingly attracted there. We therefore explore the factors that contribute to whether an international candidate stays in the U.S. or takes a job in another country. Approximately one third of our sample are candidates from the U.S. and they are placed within the U.S. with very few exceptions. Including Americans in the location analysis would significantly affect the results, so we exclude them from this analysis. We also exclude the candidates without jobs for obvious reasons. However, we include those placed to temporary jobs as they may indicate candidates' location preferences. ${ }^{14}$ The final subsample used for this location analysis includes 395 foreign candidates.

We first explore whether international candidates stay in the U.S. The dependent variable Stayus is equal to 1 if the candidate takes a U.S. job and 0 otherwise. Due to extensive heterogeneity across countries within a given continent, a seemingly better choice is to use selective country dummies. We use two criteria in selecting these countries. The first criteria is the number of candidates from that country in our sample. The second is the GDP of the candidate's home country/region. There

\footnotetext{
${ }^{14}$ The results are qualitatively the same if we exclude temporary jobs.
} 
is a lot of overlap in these two criteria and in the end we choose the following countries/regions: China, India, Korea, Russia, Turkey, Japan, Italy, Taiwan, Argentina.

Probit estimation results are presented in Table 5. Model (1) is the baseline specification, and models (2) and (3) include interaction terms between gender and country, and between gender and program ranking, respectively. In all three models, female international candidates are 5.1-6.5\% more likely to stay in the U.S. than their male counterparts (statistically insignificant), depending on the model specification. The next set of variables are country/region dummies. Some of the patterns we observed in the descriptive statistics results remain. For example, compared to the reference group, candidates from Argentina and India are most likely to work in the U.S. upon graduation, while Korean students are the least likely to stay. In addition, we have some evidence that candidates from China and Turkey are more likely to stay in the U.S. while those from Italy are less likely to stay, relative to the reference group. Moving on to other candidate characteristics, candidates are about 10\% less likely to stay if they had obtained a separate master's degree prior to joining the doctoral program. Relative to candidates from Tier 1 programs, those from lower-ranked programs are at least $28 \%$ less likely to stay in the U.S. ${ }^{15}$ The marginal effects of program quality are robust across specifications, suggesting that program quality is an important determinant of job location, perhaps through access (or lack thereof) to job networks. For each additional student in the program, the likelihood of staying in the U.S. goes down by about $1 \%$ (statistically insignificant).

$$
<<\text { Table } 5 \text { here }>>
$$

We expect dissertation advisors to impact candidates' research productivity during graduate training and their eventual job placements. Although we do not have access to the content of recommendation letters, we do know who candidates' advisors are, since this information is usually listed on the CV. Grove and Wu (2007) adopt a similar proxy for letter writers. The underlying assumption is that the more prominent the letter writer is, the better job placement will be. Interestingly, as indicated in Table 5, a candidate with a top advisor is about $30 \%$ less likely to stay in the U.S. Overall, these results remain qualitatively the same with the inclusion of interactions between gender and region/program ranking.

\subsection{Job type}

Next, we explore the likelihood of securing one of the four job types: academia, government, private sector, or temporary. Recall that visiting positions and postdocs are included in temporary jobs, not academic jobs. We estimate these probabilities using a multinomial logit model. The dependent variable equals 1 if the candidate takes a job in academia, 2 if in government, 3 if in private sector,

\footnotetext{
${ }^{15}$ Our results suggest that candidates from Tier 4 programs are more likely to stay in the U.S. than those from Tier 2 and 3 programs. That is, the relationship between job location and program ranking is U-shaped. One may speculate that foreign placements are better fits for candidates in the two middle tiers than tier 1 and 2 .
} 
and 4 if it is a temporary position. This analysis uses a sample of 559 candidates who are placed successfully (including American students).

Table 6 reports the results from multinomial logit regressions, incorporating candidate characteristics such as gender, home country/region, and program ranking, among other variables. For brevity, we do not report the estimates for temporary jobs in Table 6. Examining gender, we see that females are $7.6 \%$ less likely than males to obtain academic jobs. In contrast, women are more likely to be placed in the government and private sector but the differences are statistically insignificant. ${ }^{16}$

$$
<<\text { Table } 6 \text { here }>>
$$

Moving on to country/region dummies, there is little economical or statistical difference between American students and those from the reference group countries. However, there is substantial variation among international students. Relative to the reference group of all other countries, candidates from China and Korea are less likely to work in academia, while those from Japan and Taiwan are more likely. In columns (2) and (3), those from China and Korea more likely to find private sector jobs, and those from China, India, Russia, and Taiwan are less like to work for the government.

The impact of having an additional Master degree on job type is insignificant, as is that of program tier. Candidates from larger programs are more likely to work for the government and less likely in academia. Our results suggest that candidates with a top-four journal publication are about $32.3 \%$ more likely to be placed into academia, followed by government jobs, and are least likely to be placed into the private sector. The same pattern holds for candidates with a publication in journals ranked 5 through 50 , but to a lesser extent. Having a top-four R\&R reduces a candidate's likelihood of being placed into private sector, while having a $R \& R$ in journals ranked 5 through 50 reduces the likelihood of being placed into government jobs. One might believe that top advisors help their students secure university jobs, but we find no significant effect.

\subsection{Linking job type and job location}

\subsubsection{A theoretical framework}

In this section, we offer a stylized model to analyze the link between job type and job location. The key feature of the model is the following. In the foreign market, employers can draw from local labor supply for nonacademic jobs, but need to rely more on U.S.-educated Ph.Ds in academia. That is, there is more local competition for foreign nonacademic jobs which decreases their attractiveness

\footnotetext{
${ }^{16}$ In addition to this baseline specification, we also introduce interaction terms to investigate the gender difference within a specific country and within a program tier. Our main results remain qualitatively unchanged. Results are available from the authors upon request.
} 
and channels more candidates with a U.S.-granted Ph.D. toward foreign academic jobs. Therefore, foreign placements are more likely to be in academia than U.S. placements.

We employ a multi-dimensional Hotelling model to capture this differentiation in terms of job type (academic vs. nonacademic) and job location (U.S. or foreign). ${ }^{17}$ Agents in the Hotelling models are typically interpreted as firms and consumers, with firms choosing prices to maximize their profits and consumers choosing which firm to buy from in order to maximize their utilities. Here we interpret firms as employers and consumers as candidates. Without loss of generality, one can interpret the prices firms charge as the opposite of the salaries employers pay to candidates.

Note that employers (firms) are differentiated from each other on two dimensions: job type (academic vs. nonacademic, on the $x$-axis) and job location (within vs. outside the U.S., on the $y$-axis). There are four possible combinations or four types of employers: U.S. academic, foreign academic, U.S. nonacademic and foreign nonacademic. As indicated in Figure 4, going clockwise, firm 1 (i.e., U.S. academic) is located at $(0,0)$, firm 2 (i.e., foreign nonacademic) at $(0,1)$, firm 3 (i.e., foreign nonacademic) at $(1,1)$, and firm 4 (i.e., U.S. nonacademic) at $(1,0)$. We restrict each employer (firm) to offer only one job (product). The implication for the empirical analysis in Section 5.3.2 is that we will consider only permanent jobs and exclude temporary jobs.

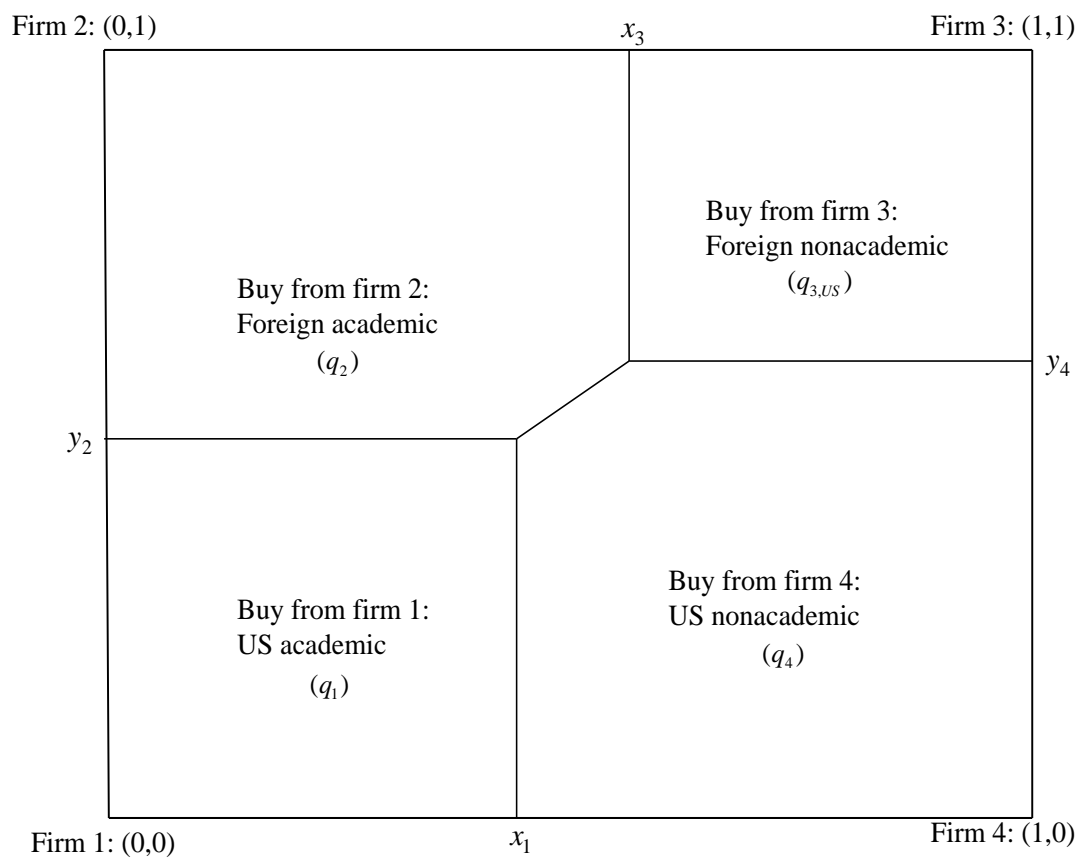

Figure 4: Job types and job location

A continuum of consumers of measure one is uniformly distributed within the square and each consumer is represented by the location $(x, y)$ where $x$ represents job type and $y$ job location. For simplicity, consumer distributions on the two dimensions are independent of each other. On the

\footnotetext{
${ }^{17}$ For studies employing multi-dimensional Hotelling models, see, for example, Gans and King (2006) and Liu and Shuai (2012).
} 
$x$-axis (i.e., job type), a location closer to 0 means that the consumer is better matched to an academic job, either because of her own preference or because the academic employer prefers her qualifications over other candidates'. As one moves on the $x$-axis towards 1 , the consumer becomes better matched to a nonacademic job. On the $y$-axis (i.e., job location), a location closer to 0 implies a better match to a U.S. placement while a location closer to 1 implies the opposite. To be exact, a consumer located at $(0,0)$ has the strongest preference for a U.S. academic job, while a consumer located at $(1,1)$ for a foreign nonacademic job. Any consumer away from the four corners will have mismatch with any of the 4 firms, and the mismatch is characterized by a disutility (transport cost in the Hotelling literature) which increases with the distance between the consumer's location and the firm's location on each dimension. In particular, consider a representative consumer located at $(x, y)$. If she buys from firm $i$ located at $(a, b)$, she will enjoy an indirect direct utility of

$$
U_{i}=V-p_{i}-t_{1}(x-a)^{2}-t_{2}(y-b)^{2},
$$

where $p_{i}$ is the price firm $i$ charges and $t_{j}$ measures consumers' intensity of preference on dimension $j=1,2$. For simplicity, we assume that $t_{1}=t_{2}=t$. Each consumer buys at most one unit from the firm which maximizes her utility. We assume that $V$ is sufficiently large so all consumers buy in the equilibrium (covered market). All firms have constant marginal cost which we normalize to zero. Firms choose prices simultaneously to maximize their respective profits.

Next, we introduce additional firm asymmetry beyond their locations. Specifically, we assume that firms 1, 2 and 4 sell only to consumers in the unit square. However, firm 3 (foreign nonacademic employer) can sell to another market and the demand from that market is represented by $q\left(p_{3}\right)$. The idea is that while foreign academic employers need to rely on the U.S.-granted Ph.D. supply, foreign nonacademic employers can draw from local labor supply who are likely willing to accept lower salary (equivalent to buying at higher price in our model). To simplify the analysis, we assume that $q\left(p_{3}\right)=a-p_{3}$ with $a>1 .{ }^{18}$

Our theory gives a testable hypothesis which is summarized in the next Proposition.

Proposition 1 Foreign placements are more likely to be academic than the U.S. placements.

\section{Proof. See Appendix A.2.}

Why are foreign placements more likely to be academic than U.S. placements? Candidates who receive a Ph.D. from the U.S. face more competition for foreign nonacademic jobs (due to the local labor supply), which reduces the attractiveness of nonacademic jobs, giving candidates more incentive to switch to either foreign academic jobs or US nonacademic jobs. Correspondingly, foreign placements are more likely to be academic, relative to U.S. placements. An alternative

\footnotetext{
${ }^{18}$ The intuition is more general than the specific choice of linear demand function. All we need is to allow firm 3 to have different demand elasticities than the other three firms, and the reason is because it also serves a foreign market with stronger demand (equivalent to lower salary).
} 
interpretation is that the criteria for success in academic jobs such as research publication is more universal, and candidates with a Ph.D. from the U.S. have advantages over local candidates. For nonacademic jobs, this advantage is likely less or may even be in the opposite direction. Therefore, foreign placements are more likely to be academic.

\subsubsection{Empirics}

The above stylized model suggests a link between job type and job location for foreign candidates. Relative to foreign candidates who stay in the U.S., those who leave the U.S. are more likely to be placed into academic jobs. Next, we test this prediction empirically. Since almost all U.S. candidates stay in the U.S., we exclude American students from this analysis. To be consistent with the theoretical model, we consider only permanent jobs and exclude temporary jobs.

Among foreign candidates who stay in the U.S., 128 and 90 are placed into academic and nonacademic jobs, respectively, implying a ratio of $\frac{128}{128+90} \approx 59 \%$ for academic placement in the U.S. For those who leave the U.S., the ratio of academic placement is $\frac{87}{87+51} \approx 63 \%$. We can see that relative to those who stay in the U.S., those who leave are more likely to be placed into academic jobs. However, the difference is small and insignificant. We then investigate our data more closely for heterogeneity across countries and find that Korean candidates behave drastically differently from those in other countries. The difference in the ratio of academic placements increases significantly if Korean candidates are removed.

Next, we test our hypothesis more formally and offer an explanation for why Korean candidates behave differently from the prediction in Proposition 1. We use Probit estimation where the dependent variable academicjob is defined as 1 if a foreign candidate is placed into academia and 0 otherwise. The variable stayus is used as an explanatory variable. ${ }^{19}$ The results are provided in Table 7. In model (1), for all foreign candidates, those who stay are $2.7 \%$ less likely to end up in academia relative to those who leave the U.S., but this difference is insignificant. From our previous descriptive statistics and estimation results, we observe significant heterogeneity across countries. Taking this into account, we introduce country/region dummies in model (2) and both country and country-stay interaction terms in model (3). In model (2), compared to candidates from the regions in the reference group, those who stay in the U.S. are $3.4 \%$ less likely to be placed into academia jobs than those who leave, but the difference remains insignificant. Moving to specification (3), the interaction term is positive and significant only for koreastay. For Korean candidates, the sum of the coefficients of stayus and koreastay is $-0.075+0.404>0$, suggesting that Korean candidates who stay in the U.S. are more likely to be placed into academia. ${ }^{20}$ Why are the results different for

\footnotetext{
${ }^{19}$ There is potential endogeneity problem using stayus as the explanatory variable as unobserved heterogeneity in the candidates may affect both decisions to choose between academic and non-academic and to choose between stay and return. However, with only a single year data, it is difficult to find good instrument variables to account for this endogeneity issue.

${ }^{20}$ This can be easily confirmed by looking at the raw data of Korean candidates. 11 of the 13 who stay in the U.S. find jobs in academia and only 2 go to the private sector. For those who leave the U.S., 3, 8 and 11 are placed to
} 
Korean students? Anecdotally, we asked some Korean Ph.D. economists we know and were told that for some of the Korean economics Ph.D. students, they were financially sponsored by various entities in Korea and are required to return to Korea after graduation, usually to work for their sponsors. We then exclude Korean candidates and re-run models (1)-(3). The results are listed in (4)-(6) of Table 7 . We can see that now the coefficient for stayus is negative and significant in models (4) and (5) but remains insignificant in model (6). ${ }^{21}$ Taken together, our estimation results largely support the prediction of our stylized model.

$$
<<\text { Table } 7 \text { here }>>
$$

\subsection{Job rank}

Next, we regress job rank on candidates' demographic and academic characteristics. We use the Kalaitzidakis, Mamuneas, and Stengos (2003) ranking (their Table 3) to rank academic jobs from 1 to 200 (lower ranks connote better jobs). Following Krueger and $\mathrm{Wu}$ (2000), we give the rank of 40 to top government jobs (e.g., IMF, World Bank, and Federal Reserve Banks) and the rank of 120 to top consulting jobs (e.g., Abt, NBER, and Rand). All remaining jobs are assigned the rank of 300. Placement in a business school is assigned five ranks better, or minus five (Krueger and Wu, 2000). Table 8 reports the estimation results from a Tobit model where the dependent variable is jobrank. In these regressions, we focus on candidates who have found a permanent job in one of the three sectors, and exclude those with temporary positions. These criteria lead to a subsample of 511 observations, including Americans and international students.

$$
<<\text { Table } 8 \text { here }>>
$$

From Table 8, our results in model (1) suggest that relative to male candidates, female candidates' placement worsens by 8.704 ranks but this difference is insignificant. The gender difference increases to 29.502 and becomes significant for the reference group in model (2) where we include gender-country interactions. The estimates for program tiers have the right sign and relative magnitude, i.e., lower tier programs are related to worse placement rank in both models. Comparing models (1) and (2), the most striking feature is probably the sharply different results in their estimates for country dummies. In particular, almost no country/region dummy has a significant coefficient in model (1) while almost all are significant in model (2). In model (1) for example, our results suggest that candidates from China are likely to be placed into worse ranked jobs relative to the reference groups. Note that this comparison considers both male and female in both groups.

academia, government, and private sector, respectively.

${ }^{21}$ We also run multinomial logit estimation similar to that in Section 5.2 but with variable stayus and country-stay interaction terms. The results are qualitatively similar to the probit estimation results here. The estimate for stayus is always negative but may be insignificant. The country-stay interaction terms are all negative except for Korea. Details are available upon request. 
In contrast, results in model (2) provide separate comparisons for male and female candidates. Relative to other male candidates, Chinese male candidates' placement is worse by 96.775 ranks. On the other hand, relative to female candidates in the reference groups, Chinese female candidates' placement improves by $128.458-96.775=31.683$ ranks. The results for other countries are similar, the country fixed effects have different signs for males and females. This is confirmed in model (4) and (5), where we divide the sample into two subsamples by gender and re-run model (1) separately for each sample. We can see that the country fixed effects have mostly different signs between model (4) (female) and model (5) (male). On the other hand, the similarity between results in model (1) and (3) suggests that there is little gender heterogeneity across program tiers.

\section{Summary of main results}

In previous subsections, we have presented results on the relationship between job placements and various candidate characteristics. To ease interpretation, we now report key results in Table 9.

\begin{tabular}{|c|c|c|c|c|c|}
\hline & \multirow[t]{2}{*}{ Job location (Stay) } & \multicolumn{3}{|c|}{ Job type } & \multirow[t]{2}{*}{ Job rank $^{(a)}$} \\
\hline & & Academic & Government & Private & \\
\hline Female & + & - & + & + & + \\
\hline China & + & - & - & + & + \\
\hline India & + & - & - & + & - \\
\hline Korea & - & - & + & + & + \\
\hline U.S. & $\mathrm{N} / \mathrm{A}$ & - & + & + & + \\
\hline Russia & - & + & - & + & + \\
\hline Argentina & + & - & - & + & - \\
\hline Program rank $^{(b)}$ & U-shaped & Non-monotonic & + & Non-monotonic & + \\
\hline Top advisor & - & + & - & - & + \\
\hline
\end{tabular}

(a): A larger number means a worse ranked job; (b) Program rank takes the value of tiers $1-4$.

Table 9. Summary of Main Findings

\section{Conclusion}

Using data on new Ph.D. economists in 2007-2008, we explore the relationship between candidate demographic/academic characteristics and job placement, as captured by type, location, and rank. Demographic characteristics include gender, nationality, and academic characteristics. Our results suggest that female candidates are less likely to be placed into academic jobs but more likely into government and private sector jobs. On average, female candidates are also placed into worse ranked jobs. We also find significant gender differences in job rank for candidates from some countries. In terms of job location, foreign female candidates are more likely to stay in the U.S. relative to foreign male candidates. 
Our results identify significant source country heterogeneity in almost all dimensions of job placement. For example, candidates from Korea are more likely to leave the U.S., while candidates from Argentina and India are more likely to stay in the U.S. We also find that having a top advisor increases the probabilities of academic placement and foreign placement, as well as improving job rank. Relative to tier 1 candidates, those from other tiers are less likely to stay in the U.S. and, not surprisingly, are placed into worse ranked jobs on average.

We also investigate the link between job location and job type. Comparing placements within the U.S. and outside for international students, which placements are more likely to be academic? Our empirical results suggest that, relative to U.S. placements, foreign placements are more likely to be in academia than nonacademia. We develop a stylized theoretical model with the following key feature: the relevant foreign market (for which Ph.D.s from American universities are good match) draws candidates from the U.S. for the academic jobs, but can draw from local talent for nonacademic jobs.

This paper contributes to the literature on the link between job characteristics and individual characteristics. In particular, we reveal new relationships between job location and job type. Thus, our analysis offers a new perspective for potential employers and graduate students and is useful for the profession. We recommend further investigation of how job location (within and outside the U.S.) affects the profession, in particular, how differences in American and other markets impact job placement.

It should be noted that our analysis is based upon placement outcomes from a single-year. Our sample is not fully exhaustive of that particular job market, though a collection of 57 programs is more comprehensive than existing studies. In future work, a more thorough appraisal of initial job placements may include (1) the evaluation of recommendation letters and of teaching abilities and (2) multiple years of data to reflect fluctuations in this job market over time. Furthermore, having multiple years of data would also alleviate endogeneity in linking job type and location by introducing valid instrument variables $(\mathrm{IVs}) .^{22}$

\section{A Appendix}

\section{A.1 Variable definitions}

(1) Demographic characteristics.

- Gender: We define a dummy variable, female, as 1 if the candidate is a female and 0 otherwise.

- Country/region: We define a set of country/region dummy variables as 1 if the candidate

\footnotetext{
${ }^{22}$ For example, the previous year's GDP of each placement country might be appropriate to use as an IV in a multi-year analysis. One would assume that the demand for new Ph.D. economists in a country, to some extent, depends on its GDP from the previous year, especially in the U.S. where these graduates are produced.
} 
comes from that country/region and 0 otherwise. They include Argentina, China, India, Italy, Japan, Korea, Russia, Taiwan, Turkey, US.

(2) Academic characteristics.

- Additional Master Degree: We define a dummy variable, addmaster, as 1 if the candidate earned a master's degree prior to entering doctoral training and 0 otherwise.

- Advisor: To control for the effectiveness of recommendation letters, we refer to Tom Coupe's index of top economists. ${ }^{23}$ We define a dummy variable, topadvisor, as 1 if the advisor and/or the co-chair is ranked top-50 economists worldwide and 0 otherwise. The underlying assumption is that the more prominent the letter writer is, the recommendation letter will likely yield better job placement (Grove and Wu, 2007).

- Top Publications: We use the journal ranking by Kalaitzidakis, Mamuneas, and Stengos (2003) to define two top journal variables. ${ }^{24}$ First, following Grove and Wu (2007), we use top 4 journal, defined as 1 if the candidate has at least one of the top four economics journals (i.e., American Economic Review (AER) (excluding Papers and Proceedings), Quarterly Journal of Economics (QJE), Journal of Political Economy (JPE), and Econometrica), and 0 otherwise. There are only 8 candidates with at least one top four journal publication at the time of application in the sample. Second, we define top5-50j, which is defined as one if the candidate has at least one publication in a journal ranked between 5 and 50 . A total of 29 candidates have at least such a publication.

- Revise and Resubmit (R\&R): To be consistent with the variables used for publications, we define two similar quality indicators for R\&Rs, using the Kalaitzidakis, Mamuneas, and Stengos (2003) ranking. First, we define a dummy variable, top $4 \mathrm{rr}$, as one if the candidate has at least one revision and resubmission in a top four journal, and zero otherwise. Second, we define a dummy variable, top5-50rr, as one if the candidate has at least one $\mathrm{R} \& \mathrm{R}$ in a journal ranked between 5 and 50 . At the time of job application in the sample, 3 of them have a top-four R\&R, and 18 have a R\&R in journals ranked 5 through 50.

- Teaching Awards: This variable measures the number of teaching awards that the candidate receives while in the Ph.D. program.

- Program Ranking: Following Buchmueller et al. (1999), we define four dummy variables for graduate program tiers. Tier 1 (tier1), Tier 2 (tier2), Tier 3 (tier3) and Tier 4 (tier4) refer

\footnotetext{
${ }^{23}$ The list of top 1000 economists is available upon request (Source:

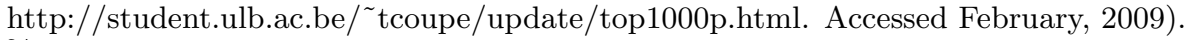

${ }^{24}$ The full list of the journal ranking is available upon request.
} 
to programs ranked 1 to 6,7 to 15,16 to 30 , and beyond 30 , respectively. ${ }^{25}$ The variable tier4 is omitted as the reference category in the analysis.

- Program Size: We define size as the total number of candidates in the program on the same job market. This variable indicates competition within the program. For instance, in larger programs, candidates face more competition from their peers with the same degree credentials. On the other hand, a larger program is more likely to offer candidates a wider network in the job market, likely facilitating their job search.

\section{(3) Placement Characteristics}

- Job Location: We define two variables regarding job location. Stayus is defined as 1 if the student accepts a job in the U.S. and 0 otherwise. Return is defined as 1 if the student accepts a job in his/her home continent and 0 otherwise. We only include foreign candidates when considering job location.

- Job Type: We divide all jobs into four types: Academia, Government, Private Sector, and Temporary Job (i.e., a visiting position or a postdoc position). Academia, Gov't, Private, Temp is defined as one if a person is placed in academia, Government, Private Sector, and Temporary Job, respectively, and zero otherwise.

In Section 5.3.2, academicjob is defined as 1 if a foreign candidate is placed into academia and 0 if $\mathrm{s} /$ he is placed into the government or the private sector.

- Job Ranking: We use the Kalaitzidakis, Mamuneas, and Stengos (2003) ranking to rank academic jobs from 1 to 200 (the lower the number, the better the job is ranked). A placement in a business school is given an extra five ranks, or minus five. Using a methodology similar to the one used in Krueger and $\mathrm{Wu}$ (2000), we give the rank of 40 to top government jobs (e.g., IMF, World Bank, and Federal Reserve Banks) and the rank of 120 to top consulting jobs (e.g., Abt, NBER, and Rand). For all the remaining jobs, we give the rank of 300. As discussed in Krueger and Wu (2000), such a ranking system is highly subjective but as we will show later, our findings are robust to different ranking systems. Therefore, candidates with unranked jobs are treated as censored observations, with the censoring point at the rank of 300 .

\section{A.2 Proof of Proposition 1}

Without the local market which the foreign nonacademic firm also serves, all firms would be symmetric and would choose the same price in a symmetric pure strategy equilibrium. However,

\footnotetext{
${ }^{25}$ Some institutions offer economics programs both in the business school and the college of arts and sciences. We treat them as different programs but give them the same rank. The list of all programs included in our sample is available upon request.
} 
asymmetry arises with the introduction of the foreign local market. Suppose that consumers in firm 3 (i.e., foreign nonacademic)'s foreign market are willing to pay higher prices (equivalent to accepting jobs with lower salaries). This means that firm 3 should charge the highest price in the equilibrium. In a partially symmetric (i.e., $p_{2}=p_{4}$ ) pure strategy equilibrium, it follows that $p_{3}>p_{2}=p_{4}>p_{1}$. Next, we derive each firm's demand conditional on all firms' equilibrium prices. Notice that in our model, each firm competes directly with two neighboring firms, but competes indirectly with only one non-neighboring firm.

Consider firm 1 for example. First, it competes with firm 4, a neighboring rival. The marginal consumer, who is indifferent between buying from either firm, is characterized by

$$
U_{1}=U_{4} \Rightarrow x=x_{1}=\frac{p_{4}-p_{1}+t}{2 t}
$$

Second, firm 1 also competes with firm 2, another neighboring rival, and the corresponding marginal consumer is represented by

$$
U_{1}=U_{2} \Rightarrow y=y_{2}=\frac{p_{2}-p_{1}+t}{2 t}
$$

Similarly, firm 3 competes with two neighboring rivals, firms 2 and 4, and the marginal consumers are characterized by

$$
x_{3}=\frac{p_{3}-p_{2}+t}{2 t}, \quad y_{4}=\frac{p_{3}-p_{4}+t}{2 t} .
$$

With $p_{2}=p_{4}$, it can be easily verified that $x_{1}-x_{3}=y_{2}-y_{4}$. There are then two possibilities for which we consider separately: $x_{1} \leq x_{3}$ in the first case and $x_{1}>x_{3}$ in the second case. We verify that no equilibrium exists in the second case. In the first case, from Figure 4, the firms' demand functions are

$$
\begin{gathered}
q_{1}=x_{1} y_{1}, \\
q_{2}=x_{3}\left(1-y_{2}\right)-\frac{1}{2}\left(x_{3}-x_{1}\right)\left(y_{4}-y_{2}\right), \\
q_{3}=q_{3, U S}+q_{3, \text { foreign }}, \quad q_{3, U S}=x_{3} y_{4}, \quad q_{3, \text { foreign }}=\left(a-p_{3}\right), \\
q_{4}=\left(1-x_{1}\right) y_{4}-\frac{1}{2}\left(x_{3}-x_{1}\right)\left(y_{4}-y_{2}\right) .
\end{gathered}
$$

Firm $i=1, \ldots 4$ 's profit is

$$
\pi_{i}=p_{i} q_{i}
$$

and the first-order condition (FOC) is given by

$$
\frac{\partial \pi_{i}}{\partial p_{i}}=0
$$


Imposing a partial symmetry in prices $\left(p_{4}=p_{2}\right)$, we then solve firm 1's FOC to obtain

$$
p_{1}=\frac{p_{2}+t}{3}
$$

and firm 2's to obtain

$$
p_{2}=\frac{-31 t+9 p_{3}+6 \sqrt{35 t^{2}-9 t p_{3}-p_{3}^{2}}}{13} .
$$

Substituting $p_{1}$ and $p_{2}$ into firm 3's FOC, we have

$$
\frac{\partial \pi_{3}}{\partial p_{3}}=-\frac{-396 t^{2}-72 t p_{3}+\left(54 t+51 p_{3}\right) \sqrt{35 t^{2}-9 t p_{3}-p_{3}^{2}}-21 p_{3}^{2}-169 a t^{2}+338 p_{3} t^{2}}{169 t^{2}}=0 .
$$

Absence from a closed-form solution for $p_{3}$, we thus rely on numerical results. We first normalize $t=1$ and then restrict $a \in(1,3]$ so that firm 3's foreign market is stronger than the U.S. market (lower salary) but not too strong so that firm 3 still makes sales in the U.S. market. The results are qualitatively similar for any $a \in(1,3]$. Let $a=2$ and the corresponding equilibrium prices are

$$
p_{1} \approx 05322, \quad p_{2}=p_{4} \approx 0.5966, \quad p_{3} \approx 0.9035
$$

Under these prices, the $x_{1}<x_{3}$ constraint is satisfied since

$$
0<x_{1}=y_{2}<x_{3}=y_{4}<1
$$

Firms' demand are

$$
q_{1}=0.2833, \quad q_{2}=0.2983, \quad q_{3, U S}=0.1201, \quad q_{4}=0.2983 .
$$

In our theory model, $q_{1}$ and $q_{4}$ are the measures of the U.S. academic placement and the U.S. nonacademic placement, respectively. The ratio of academic jobs in the U.S. placements is $\frac{q_{1}}{q_{1}+q_{4}} \approx 49 \%$. Similarly, the ratio of academic jobs in foreign placements is $\frac{q_{2}}{q_{2}+q_{3, U S}} \approx 71 \%$.

\section{References}

[1] Athey, S., L. Katz, A. Krueger, S. Levitt, and J. Poterba (2007). "What Does Performance in Graduate School Predict? Graduate economics Education and Student Outcomes," AEA Papers and Proceedings, 97(2), 512-518.

[2] Barbezat, D. (1992). "The Market for New Ph.D. Economists." Journal of Economic Education, 23(3), 262-276.

[3] Blackaby, D., A. Booth, and J. Frank (2005). "Outside Offers and the Gender Pay Gap: Empirical Evidence from the UK Academic Labour Market," Economic Journal, 115, 81-107. 
[4] Blackaby, D. and J. Frank (2000). "Ethnic and other minority representation in UK academic economics." Economic Journal, 110, 293-311.

[5] Broder, I. (1993). "Professional Achievements and Gender Differences among Academic Economists." Economic Inquiry, 31(1), 116-127.

[6] Buchmueller, T., J. Dominitz, and W. Hansen (1999). "Graduate Training and the Early Career Productivity of Ph.D. economists," Economics of Education Review, 14, 65-77.

[7] Cawley, J. (2011). "A Guide (and Advice) for Economists on the U. S. Junior Academic Job Market."

[8] Collins, S. (2000). "Minority groups in the economics profession." Journal of Economic Perspectives, 14(2), 133-148.

[9] Ehrenberg, R. (2004). "Econometric studies of higher education." Journal of Econometrics 121, 19-37.

[10] Coupe, T. (2004). "What Do We Know about Ourselves? On the economics of economics," Kyklos, 57, 197-216.

[11] Gallet, C., J. List and P. Orazem (2005). "Cyclicality and the Labor Market for Economists," Southern Economic Journal, 72(2), 284-304.

[12] Gans, J. and S. King (2006) "Paying for Loyalty: Product Bundling in Oligopoly," Journal of Industrial Economics, 54(1), 43-62.

[13] Ginther, D., and K. Hayes (2003). "Gender Differences in Salary and Promotion for Faculty in the Humanities 1977-95," Journal of Human Resources, 38(1), 34-73.

[14] Grove, W., D. Dutkowsky and A. Grodner (2007). "Survive Then Thrive: Determinants of Success in the economics Ph.D. Program," Economic Inquiry, 45(4), 864-871.

[15] Grove, W. and S. Wu (2007), "The Search for Economics Talent: Doctoral Completion and Research productivity," AEA Papers and Proceedings, 97(2), 506-511.

[16] Hilmer, C., and M. Hilmer. (2007). "Women Helping Women, Men Helping Women? SameGender. Mentoring, Initial Job Placements, and Early Career Publishing," AEA Papers and Proceedings 97(2), 422-426.

[17] Kahn, S. (1995). "Women in the Economics Profession." Journal of Economic Perspectives 9(4), 193-206.

[18] Kalaitzidakis, P., T. Mamuneas, and T. Stengos (2003). "Rankings of Academic Journals and Institutions," Working Papers 2003-8, University of Guelph, Department of Economics. 
[19] Kolpin, V., and L. Singell, Jr. (1996). "The Gender Composition and Scholarly Performance of economics Departments: A Test for Employment Discrimination," Industrial and Labor Relations Review, 49(3), 408-423.

[20] Krause A., U. Rinne and K. Zimmermanna (2012). "Anonymous job applications of fresh Ph.D. economists." Economics Letters, 117, 441-444.

[21] Krueger A. and S. Wu (2000). "Forecasting Job Placements of Economics Graduate Students," Journal of Economic Education, winter, 81-94.

[22] Liu, Q. and J. Shuai (2012). "Multi-dimensional product differentiation," Working paper.

[23] McDowell, J., L. Singell, Jr., and J. Ziliak (1999). "Cracks in the Glass Ceiling: Gender and Promotion in the economics Profession," AEA Papers and Proceedings, 89(2), 392-396.

[24] McDowell, J., L. Singell, Jr., and J. Ziliak (2001). "Gender and Promotion in the economics Profession," Industrial and Labor Relations Review, 54(2), 224-244.

[25] McMillen, D., and L. Singell, Jr. (1994). "Gender Differences in First Jobs for economists," Southern Economic Journal, 60(3), 701-704.

[26] Neumark, D. and R. Gardecki (1998). "Women helping women? Role model and mentoring effects on female PhD students in economics." Journal of Human Resources, 33(1), 220-246.

[27] Oyer, P. (2006). "Initial Labor Market Conditions and Long-Term Outcomes for economists," Journal of Economic Perspectives, 20(3), 143-160.

[28] Siegfried, J. and W. Stock (1999). "The Labor Market for New Ph.D. economists," Journal of Economic Perspectives, 13(3), 115-134.

[29] Siegfried, J. and W. Stock (2001). "So you want to earn a Ph.D. in Economics: How Long Do You Think it Will Take?" Journal of Human Resources, 36(2), 364-378.

[30] Siegfried, J. and W. Stock (2004). "The Market for New Ph.D. economists in 2002," $A E A$ Papers and Proceedings, 94(2), 272-285.

[31] Stock, W. and R. Alston (2000). "Effect of graduate-program rank on success in the job market." Journal of Economic Education, 31(4), 389-401.

[32] Stock, W. and J. Siegfried (2001). "So you want to earn a Ph.D. in Economics: How much do you think you'll make?" Economic Inquiry, 39(2), 320-335.

[33] Stock, W. and J. Siegfried (2006a). "Time-to-Degree for the Economics Ph.D. Class of 20012002," AEA Papers and Proceedings.

[34] Stock, W. and J. Siegfried (2006b). "Where Are They Now? Tracking the Ph.D. Class of 1997." Southern Economic Journal, 73(2), 473-488. 
Figure 1. Percent PhD Students Who are Female

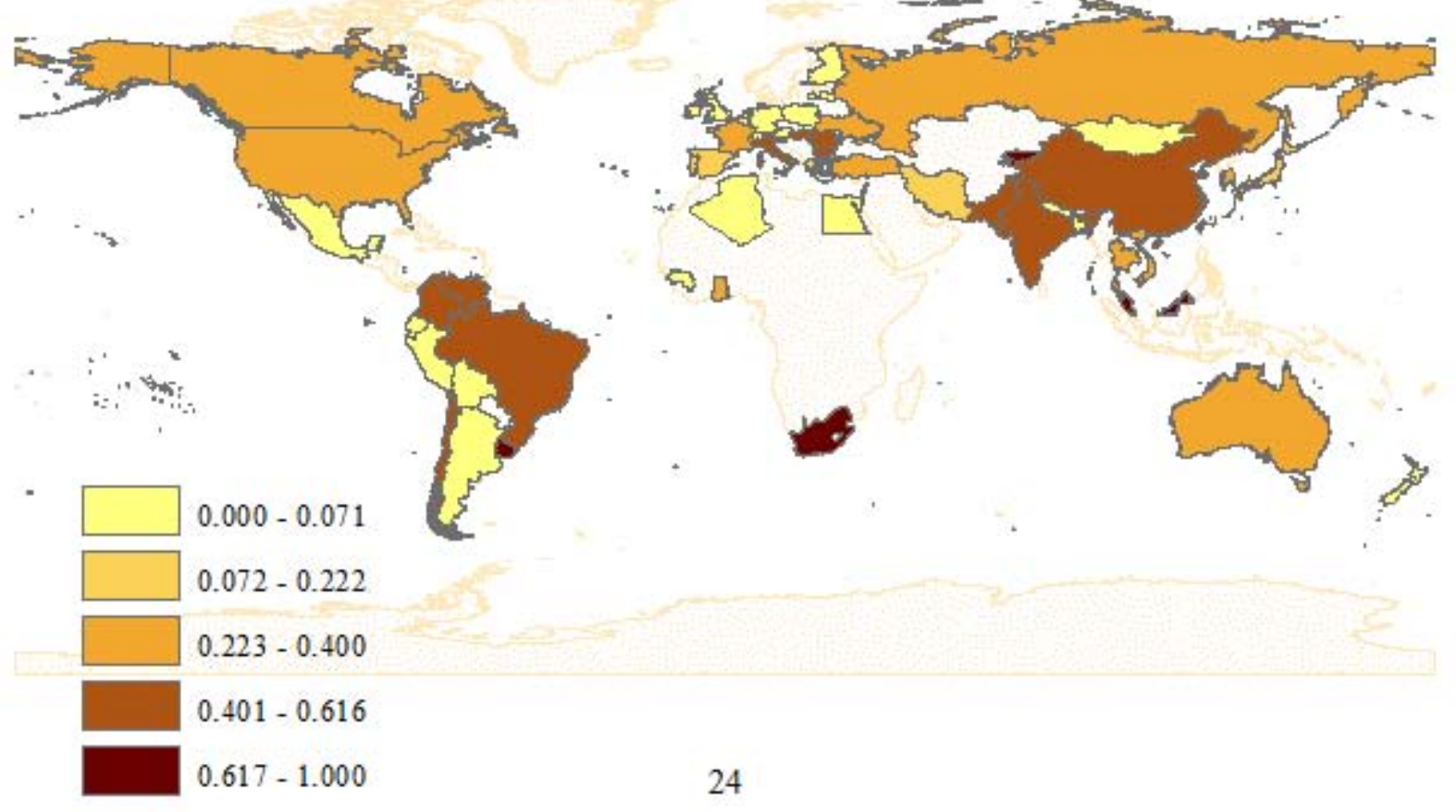




\section{Figure 2. Percent PhD Students Who Stay in U.S.}

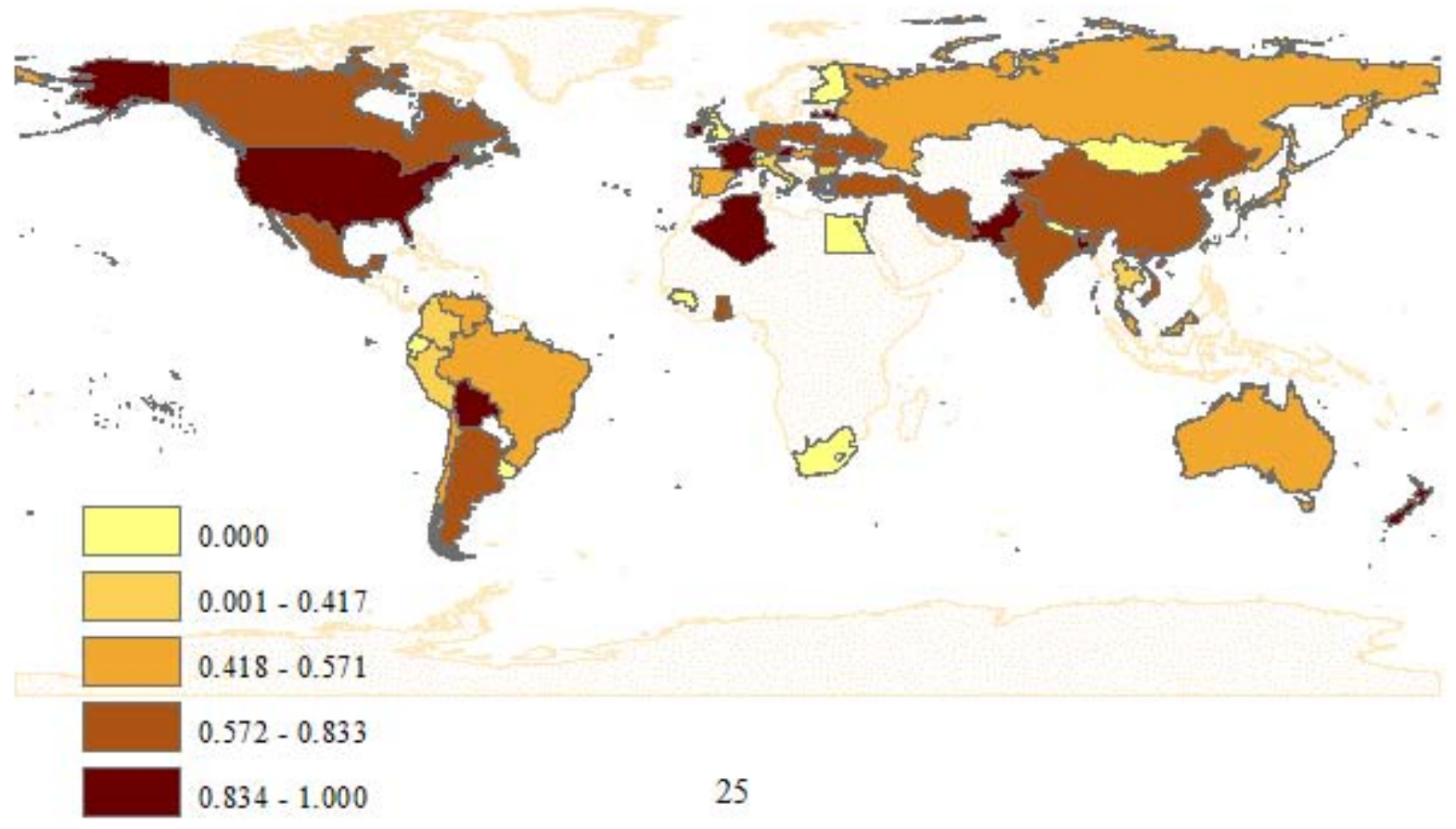


Figure 3. Percent PhD Students Who Return to Home Country

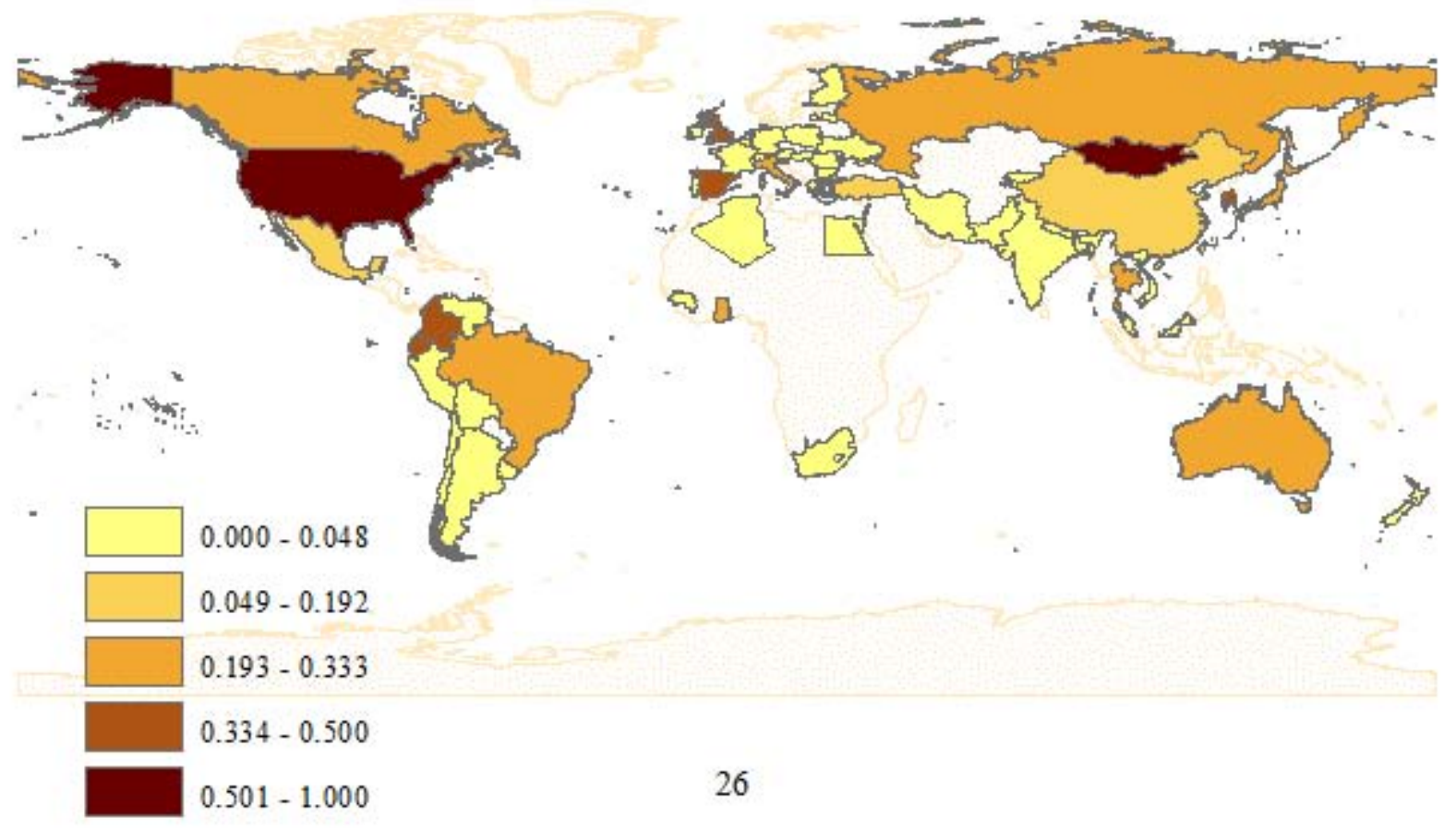


Table 1. Female and Foreign student Ratios by Program Ranking

\begin{tabular}{lrrrrr}
\hline Program Ranking & Total & \multicolumn{2}{c}{ Female } & Female Ratio Foreign & Foreign Ratio \\
Tier1 & 136 & 46 & $34 \%$ & 83 & $61 \%$ \\
Tier2 & 115 & 40 & $35 \%$ & 90 & $78 \%$ \\
Tier3 & 174 & 60 & $34 \%$ & 131 & $75 \%$ \\
Tier4 & 153 & 53 & $35 \%$ & 105 & $69 \%$ \\
Total & 578 & 199 & $34 \%$ & 409 & $71 \%$ \\
\hline
\end{tabular}

Table 2. Summary Statistics of Academic Characteristics

\begin{tabular}{|c|c|c|c|c|c|}
\hline Variable & Obs & Mean & Std. Dev. & Min & Max \\
\hline Addional master degree & 578 & 0.51 & 0.50 & 0 & 1 \\
\hline Topadvisor & 578 & 0.04 & 0.21 & 0 & 1 \\
\hline top4j & 578 & 0.01 & 0.12 & 0 & 1 \\
\hline top5-50j & 578 & 0.05 & 0.22 & 0 & 1 \\
\hline top4rr & 578 & 0.01 & 0.07 & 0 & 1 \\
\hline top5-50rr & 578 & 0.03 & 0.17 & 0 & 1 \\
\hline Teaching awards & 578 & 0.26 & 0.61 & 0 & 4 \\
\hline Size & 578 & 14.19 & 7.52 & 1 & 32 \\
\hline
\end{tabular}


Table 3. Foreign Students' Stay In the U.S. and Return-to-Home Continent Ratio

\begin{tabular}{lrrrrr}
\hline & Total & Stay & ratio & return & ratio \\
overall & 395 & 249 & $63 \%$ & 113 & $29 \%$ \\
by gender & & & & & \\
male & 254 & 152 & $60 \%$ & 80 & $31 \%$ \\
female & 141 & 97 & $69 \%$ & 33 & $23 \%$ \\
& & & & & \\
by program tier & & & & & \\
tier1 & 83 & 63 & $76 \%$ & 20 & $24 \%$ \\
tier2 & 88 & 52 & $59 \%$ & 27 & $31 \%$ \\
tier3 & 122 & 70 & $57 \%$ & 42 & $34 \%$ \\
tier4 & 102 & 64 & $63 \%$ & 24 & $24 \%$ \\
& & & & & \\
by continent & & & & 1 & $14 \%$ \\
Africa & 7 & 3 & $43 \%$ & 53 & $27 \%$ \\
Asia & 194 & 117 & $60 \%$ & 2 & $25 \%$ \\
Australia & 8 & 5 & $63 \%$ & 41 & $37 \%$ \\
Europe & 111 & 64 & $58 \%$ & 6 & $13 \%$ \\
Latin Americ & 45 & 26 & $58 \%$ & 3 & $8 \%$ \\
Mideast & 36 & 29 & $81 \%$ & 7 & $88 \%$ \\
Canada & 8 & 5 & $63 \%$ & &
\end{tabular}

Note: the sum of Stay and Return may not add up to Total. For example, candidates may be placed in a third continent other than their home continent or the U.S.

In addition, Canadian candidates who return to home continent may be placed in either Canada or the U.S. 
Table 4. The Job Type of All Candidates

\begin{tabular}{|c|c|c|c|c|c|c|c|c|c|}
\hline \multirow{2}{*}{$\begin{array}{l}\text { Job Types } \\
\text { Overall }\end{array}$} & \multirow{2}{*}{$\begin{array}{l}\text { Academia } \\
\text { Count }\end{array}$} & \multicolumn{2}{|c|}{ Gov't } & \multicolumn{2}{|r|}{ Private } & \multicolumn{3}{|c|}{ Temp } & \multirow[t]{2}{*}{ Total } \\
\hline & & Percent & Count & Percent & Count & Percent & Count & Percent & \\
\hline & 309 & $55 \%$ & 77 & $14 \%$ & 125 & $22 \%$ & 48 & $9 \%$ & 559 \\
\hline \multicolumn{10}{|l|}{ Gender } \\
\hline Female & 94 & $49 \%$ & 29 & $15 \%$ & 52 & $27 \%$ & 17 & $9 \%$ & 192 \\
\hline Male & 215 & $59 \%$ & 48 & $13 \%$ & 73 & $20 \%$ & 31 & $8 \%$ & 367 \\
\hline \multicolumn{10}{|l|}{ Program Tier } \\
\hline Tier1 & 76 & $56 \%$ & 21 & $16 \%$ & 30 & $22 \%$ & 8 & $6 \%$ & 135 \\
\hline Tier2 & 61 & $54 \%$ & 14 & $13 \%$ & 27 & $24 \%$ & 10 & $9 \%$ & 112 \\
\hline Tier3 & 93 & $57 \%$ & 22 & $13 \%$ & 35 & $21 \%$ & 14 & $9 \%$ & 164 \\
\hline Tier4 & 79 & $53 \%$ & 20 & $14 \%$ & 33 & $22 \%$ & 16 & $11 \%$ & 148 \\
\hline \multicolumn{10}{|l|}{ Continent } \\
\hline Africa & 2 & $29 \%$ & 2 & $29 \%$ & 2 & $29 \%$ & 1 & $14 \%$ & 7 \\
\hline Asia & 97 & $52 \%$ & 20 & $11 \%$ & 54 & $29 \%$ & 15 & $8 \%$ & 186 \\
\hline Australia & 4 & $50 \%$ & 3 & $38 \%$ & 0 & $0 \%$ & 1 & $13 \%$ & 8 \\
\hline Europe & 66 & $61 \%$ & 12 & $11 \%$ & 19 & $18 \%$ & 11 & $10 \%$ & 108 \\
\hline Latin America & 22 & $51 \%$ & 5 & $12 \%$ & 11 & $26 \%$ & 5 & $12 \%$ & 43 \\
\hline Mideast & 19 & $54 \%$ & 6 & $17 \%$ & 4 & $11 \%$ & 6 & $17 \%$ & 35 \\
\hline North America & 99 & $58 \%$ & 29 & $17 \%$ & 35 & $20 \%$ & 9 & $5 \%$ & 172 \\
\hline
\end{tabular}


Table 5. Marginal Effects of Probit Analysis on Job Location (Foreign Candidates Only)

\begin{tabular}{|c|c|c|c|}
\hline VARIABLES & (1) & $(2)$ & (3) \\
\hline \multirow[t]{2}{*}{ Female } & 0.063 & 0.051 & 0.065 \\
\hline & $(0.052)$ & $(0.101)$ & $(0.054)$ \\
\hline \multirow[t]{2}{*}{ China } & $0.132 *$ & 0.055 & $0.132 *$ \\
\hline & $(0.074)$ & (0.109) & $(0.074)$ \\
\hline \multirow[t]{2}{*}{ India } & $0.150 *$ & $0.251 * * *$ & $0.150 *$ \\
\hline & $(0.083)$ & $(0.095)$ & $(0.083)$ \\
\hline \multirow[t]{2}{*}{ Korea } & $-0.227^{* *}$ & $-0.214^{*}$ & $-0.227 * *$ \\
\hline & $(0.102)$ & (0.113) & $(0.102)$ \\
\hline \multirow[t]{2}{*}{ Russia } & -0.100 & -0.126 & -0.100 \\
\hline & $(0.118)$ & $(0.124)$ & (0.119) \\
\hline \multirow[t]{2}{*}{ Turkey } & 0.170 & $0.246^{* * *}$ & 0.170 \\
\hline & $(0.105)$ & $(0.077)$ & (0.105) \\
\hline \multirow[t]{2}{*}{ Japan } & -0.121 & -0.152 & -0.121 \\
\hline & $(0.144)$ & $(0.167)$ & $(0.144)$ \\
\hline \multirow[t]{2}{*}{ Italy } & -0.217 & $-0.431 * *$ & -0.217 \\
\hline & $(0.144)$ & $(0.167)$ & $(0.143)$ \\
\hline \multirow[t]{2}{*}{ Taiwan } & -0.046 & -0.157 & -0.047 \\
\hline & $(0.155)$ & $(0.220)$ & $(0.156)$ \\
\hline \multirow[t]{2}{*}{ Argentina } & $0.308 * * *$ & $0.306 * * *$ & $0.307 * * *$ \\
\hline & $(0.044)$ & $(0.044)$ & $(0.046)$ \\
\hline \multirow[t]{2}{*}{ Additional master degree } & $-0.101^{*}$ & $-0.101^{*}$ & $-0.101^{*}$ \\
\hline & $(0.052)$ & $(0.056)$ & $(0.052)$ \\
\hline \multirow[t]{2}{*}{ Ph.D. tier 2} & $-0.301 * * *$ & $-0.304^{* * *}$ & $-0.297 * * *$ \\
\hline & $(0.082)$ & $(0.083)$ & $(0.099)$ \\
\hline \multirow[t]{2}{*}{ Ph.D. tier 3} & $-0.279 * * *$ & $-0.276^{* * *}$ & $-0.279 * * *$ \\
\hline & $(0.084)$ & $(0.087)$ & $(0.084)$ \\
\hline \multirow[t]{2}{*}{ Ph.D. tier 4} & $-0.276^{* * *}$ & $-0.277^{* * *}$ & $-0.276 * * *$ \\
\hline & $(0.096)$ & $(0.098)$ & $(0.096)$ \\
\hline \multirow[t]{2}{*}{ Size } & -0.007 & -0.007 & -0.007 \\
\hline & $(0.004)$ & $(0.004)$ & $(0.004)$ \\
\hline \multirow[t]{2}{*}{ Teaching awards } & 0.006 & -0.004 & 0.006 \\
\hline & $(0.042)$ & $(0.045)$ & $(0.042)$ \\
\hline \multirow[t]{2}{*}{ top4j } & -0.028 & -0.070 & -0.028 \\
\hline & $(0.183)$ & $(0.174)$ & $(0.183)$ \\
\hline \multirow[t]{2}{*}{ top5-50j } & -0.149 & -0.121 & -0.149 \\
\hline & $(0.111)$ & $(0.113)$ & $(0.111)$ \\
\hline \multirow[t]{2}{*}{ top5-50rr } & 0.161 & 0.131 & 0.162 \\
\hline & $(0.128)$ & $(0.139)$ & $(0.129)$ \\
\hline \multirow[t]{2}{*}{ Topadvisor } & $-0.299 * *$ & $-0.293^{*}$ & $-0.299 * *$ \\
\hline & $(0.143)$ & $(0.159)$ & $(0.144)$ \\
\hline Female*County Dummy & $\mathrm{N}$ & $\mathrm{Y}$ & $\mathrm{N}$ \\
\hline Female*Program Tier & $\mathrm{N}$ & $\mathrm{N}$ & $\mathrm{Y}$ \\
\hline Observations & 394 & 394 & 394 \\
\hline Pseudo R-squared & 0.0998 & 0.113 & 0.0998 \\
\hline
\end{tabular}

Robust standard errors in parentheses $* * * \mathrm{p}<0.01,{ }^{* *} \mathrm{p}<0.05,{ }^{*} \mathrm{p}<0.1$ 
Table 6. Marginal Effects of Multinomial Logit Analysis on Job Type (All Candidates)

\begin{tabular}{|c|c|c|c|}
\hline Placement Type & $\begin{array}{c}(1) \\
\text { Academic }\end{array}$ & $\begin{array}{c}(2) \\
\text { Government }\end{array}$ & $\begin{array}{c}(3) \\
\text { Private } \\
\end{array}$ \\
\hline Female & $\begin{array}{l}-0.076^{*} \\
(0.045)\end{array}$ & $\begin{array}{c}0.020 \\
(0.016)\end{array}$ & $\begin{array}{c}0.054 \\
(0.047)\end{array}$ \\
\hline U.S. & $\begin{array}{l}-0.019 \\
(0.061)\end{array}$ & $\begin{array}{c}0.004 \\
(0.018)\end{array}$ & $\begin{array}{c}0.026 \\
(0.055)\end{array}$ \\
\hline China & $\begin{array}{l}-0.124^{*} \\
(0.065)\end{array}$ & $\begin{array}{c}-0.034 * * \\
(0.016)\end{array}$ & $\begin{array}{c}0.167 * * \\
(0.069)\end{array}$ \\
\hline India & $\begin{array}{l}-0.027 \\
(0.075)\end{array}$ & $\begin{array}{c}-0.040 * * \\
(0.019)\end{array}$ & $\begin{array}{c}0.070 \\
(0.073)\end{array}$ \\
\hline Korea & $\begin{array}{c}-0.209 * * \\
(0.100)\end{array}$ & $\begin{array}{c}0.019 \\
(0.034)\end{array}$ & $\begin{array}{c}0.200 * * \\
(0.096)\end{array}$ \\
\hline Russia & $\begin{array}{c}0.033 \\
(0.091)\end{array}$ & $\begin{array}{c}-0.100 * * * \\
(0.011)\end{array}$ & $\begin{array}{c}0.093 \\
(0.091)\end{array}$ \\
\hline Turkey & $\begin{array}{c}0.013 \\
(0.109)\end{array}$ & $\begin{array}{c}0.015 \\
(0.045)\end{array}$ & $\begin{array}{l}-0.034 \\
(0.113)\end{array}$ \\
\hline Japan & $\begin{array}{l}0.152^{*} \\
(0.086)\end{array}$ & $\begin{array}{l}-0.034 \\
(0.023)\end{array}$ & $\begin{array}{l}-0.117 \\
(0.089)\end{array}$ \\
\hline Italy & $\begin{array}{l}-0.060 \\
(0.147)\end{array}$ & $\begin{array}{c}0.004 \\
(0.054)\end{array}$ & $\begin{array}{c}0.076 \\
(0.140)\end{array}$ \\
\hline Taiwan & $\begin{array}{l}0.182 * \\
(0.094)\end{array}$ & $\begin{array}{c}-0.077 * * * \\
(0.008)\end{array}$ & $\begin{array}{l}-0.105 \\
(0.095)\end{array}$ \\
\hline Argentina & $\begin{array}{l}-0.044 \\
(0.178)\end{array}$ & $\begin{array}{l}-0.024 \\
(0.039)\end{array}$ & $\begin{array}{c}0.088 \\
(0.170)\end{array}$ \\
\hline Additional master degree & $\begin{array}{c}0.002 \\
(0.040)\end{array}$ & $\begin{array}{c}0.007 \\
(0.015)\end{array}$ & $\begin{array}{l}-0.009 \\
(0.035)\end{array}$ \\
\hline Ph.D. tier 2 & $\begin{array}{l}-0.024 \\
(0.061)\end{array}$ & $\begin{array}{c}0.003 \\
(0.024)\end{array}$ & $\begin{array}{c}0.020 \\
(0.062)\end{array}$ \\
\hline Ph.D. tier 3 & $\begin{array}{c}0.017 \\
(0.049)\end{array}$ & $\begin{array}{c}0.004 \\
(0.013)\end{array}$ & $\begin{array}{l}-0.025 \\
(0.049)\end{array}$ \\
\hline Ph.D. tier 4 & $\begin{array}{l}-0.048 \\
(0.064)\end{array}$ & $\begin{array}{c}0.018 \\
(0.024)\end{array}$ & $\begin{array}{c}0.028 \\
(0.065)\end{array}$ \\
\hline Size & $\begin{array}{l}-0.005^{*} \\
(0.003)\end{array}$ & $\begin{array}{c}0.002^{* *} \\
(0.001)\end{array}$ & $\begin{array}{c}0.004 \\
(0.003)\end{array}$ \\
\hline Teaching awards & $\begin{array}{c}0.009 \\
(0.044)\end{array}$ & $\begin{array}{l}-0.007 \\
(0.011)\end{array}$ & $\begin{array}{l}-0.003 \\
(0.039)\end{array}$ \\
\hline top4j & $\begin{array}{c}0.323 * * * \\
(0.021)\end{array}$ & $\begin{array}{c}-0.068 * * * \\
(0.007)\end{array}$ & $\begin{array}{c}-0.237 * * * \\
(0.022)\end{array}$ \\
\hline top4rr & $\begin{array}{c}0.075 \\
(0.311)\end{array}$ & $\begin{array}{c}0.156 \\
(0.307)\end{array}$ & $\begin{array}{c}-0.215^{* * * *} \\
(0.020)\end{array}$ \\
\hline top5-50j & $\begin{array}{c}0.165^{* * *} \\
(0.064)\end{array}$ & $\begin{array}{l}-0.018 \\
(0.026)\end{array}$ & $\begin{array}{c}-0.145^{* * * *} \\
(0.056)\end{array}$ \\
\hline top5-50rr & $\begin{array}{c}0.037 \\
(0.088)\end{array}$ & $\begin{array}{l}-0.039 * \\
(0.022)\end{array}$ & $\begin{array}{c}0.026 \\
(0.087)\end{array}$ \\
\hline topadvisor & $\begin{array}{c}0.043 \\
(0.069)\end{array}$ & $\begin{array}{l}-0.008 \\
(0.036)\end{array}$ & $\begin{array}{l}-0.034 \\
(0.080)\end{array}$ \\
\hline Observations & 559 & 559 & 559 \\
\hline Pseudo R-squared & 0.0691 & 0.0691 & 0.0691 \\
\hline
\end{tabular}


Table 7. Marginal Effects of Probit Analysis on Job Location and Job Type

(Foreign Candidates Only)

\begin{tabular}{|c|c|c|c|c|c|c|}
\hline \multirow[t]{2}{*}{ VARIABLES } & \multirow{2}{*}{\multicolumn{3}{|c|}{$\begin{array}{c}(2) \\
\text { All Foreign Candidates }\end{array}$}} & \multirow{2}{*}{\multicolumn{3}{|c|}{$\begin{array}{lcr}(4) & (5) & (6) \\
\text { Korean Candidates Excluded }\end{array}$}} \\
\hline & & & & & & \\
\hline Stayus & $\begin{array}{l}-0.027 \\
(0.066)\end{array}$ & $\begin{array}{l}-0.034 \\
(0.071)\end{array}$ & -0.075 & $\begin{array}{l}-0.134 * * \\
(0.058)\end{array}$ & $-0.122 * *$ & -0.070 \\
\hline \multirow[t]{2}{*}{ Female } & $-0.092 *$ & -0.083 & -0.062 & $-0.098^{*}$ & -0.084 & -0.073 \\
\hline & $(0.051)$ & $(0.057)$ & $(0.055)$ & $(0.052)$ & $(0.060)$ & $(0.059)$ \\
\hline China & & -0.104 & 0.073 & & -0.087 & 0.075 \\
\hline \multirow{2}{*}{ India } & & 0.033 & 0.049 & & 0.033 & 0.046 \\
\hline & & $(0.089)$ & $(0.185)$ & & $(0.086)$ & $(0.182)$ \\
\hline Korea & & $\begin{array}{c}-0.206^{* *} \\
(0.099)\end{array}$ & $\begin{array}{c}-0.545^{* * *} \\
(0.090)\end{array}$ & & - & - \\
\hline \multirow[t]{2}{*}{ Russia } & & 0.063 & 0.123 & & 0.041 & 0.114 \\
\hline & & $(0.097)$ & (0.133) & & $(0.101)$ & (0.132) \\
\hline \multirow[t]{2}{*}{ Turkey } & & -0.038 & -0.203 & & -0.043 & -0.191 \\
\hline & & $(0.124)$ & $(0.275)$ & & $(0.123)$ & $(0.281)$ \\
\hline \multirow[t]{2}{*}{ Japan } & & $0.213^{*}$ & 0.148 & & $0.194 *$ & 0.142 \\
\hline & & (0.109) & (0.198) & & $(0.116)$ & (0.189) \\
\hline \multirow[t]{2}{*}{ Italy } & & -0.113 & -0.124 & & -0.114 & -0.133 \\
\hline & & $(0.170)$ & $(0.236)$ & & $(0.168)$ & $(0.232)$ \\
\hline \multirow[t]{2}{*}{ Taiwan } & & $0.285^{* *}$ & $0.415^{* * *}$ & & $0.269 * *$ & $0.394 * * *$ \\
\hline & & $(0.112)$ & $(0.027)$ & & $(0.106)$ & $(0.029)$ \\
\hline \multirow[t]{2}{*}{ Argentina } & & -0.039 & $0.425 * * *$ & & -0.015 & $0.404^{* * *}$ \\
\hline & & $(0.202)$ & $(0.027)$ & & (0.198) & $(0.029)$ \\
\hline \multirow[t]{2}{*}{ China*Stayus } & & & -0.243 & & & -0.236 \\
\hline & & & (0.168) & & & (0.174) \\
\hline \multirow[t]{2}{*}{ India*Stayus } & & & -0.037 & & & -0.033 \\
\hline & & & (0.249) & & & $(0.246)$ \\
\hline \multirow[t]{2}{*}{ Russia*Stayus } & & & -0.152 & & & -0.154 \\
\hline & & & (0.304) & & & $(0.306)$ \\
\hline \multirow[t]{2}{*}{ Turkey*Stayus } & & & 0.193 & & & 0.173 \\
\hline & & & (0.197) & & & $(0.196)$ \\
\hline \multirow[t]{2}{*}{ Korea*Stayus } & & & $0.404^{* * *}$ & & & - \\
\hline & & & $(0.027)$ & & & \\
\hline \multirow[t]{2}{*}{ Japan*Stayus } & & & 0.130 & & & 0.118 \\
\hline & & & $(0.292)$ & & & $(0.285)$ \\
\hline \multirow[t]{2}{*}{ Italy*Stayus } & & & 0.019 & & & 0.044 \\
\hline & & & $(0.237)$ & & & $(0.218)$ \\
\hline \multirow[t]{2}{*}{ Taiwan*Stayus } & & & $-0.647 * * *$ & & & $-0.673 * * *$ \\
\hline & & & $(0.025)$ & & & $(0.025)$ \\
\hline \multirow[t]{2}{*}{ Argentina*Stayus } & & & $-0.678 * * *$ & & & $-0.707^{* * *}$ \\
\hline & & & $(0.023)$ & & & $(0.024)$ \\
\hline Additional master degree & -0.017 & -0.046 & -0.029 & 0.023 & -0.003 & -0.005 \\
\hline & $(0.051)$ & $(0.051)$ & (0.049) & $(0.052)$ & $(0.052)$ & $(0.050)$ \\
\hline Ph.D. tier 2 & 0.088 & 0.094 & 0.093 & 0.090 & 0.100 & 0.100 \\
\hline & $(0.080)$ & $(0.078)$ & $(0.085)$ & $(0.083)$ & $(0.083)$ & $(0.083)$ \\
\hline Ph.D. tier 3 & $0.103^{* *}$ & $0.114^{* *}$ & $0.143 * * *$ & $0.126^{* *}$ & $0.134 * *$ & $0.138 * * *$ \\
\hline & $(0.048)$ & $(0.050)$ & $(0.054)$ & $(0.052)$ & $(0.053)$ & $(0.051)$ \\
\hline
\end{tabular}




\begin{tabular}{|c|c|c|c|c|c|c|}
\hline Ph.D. tier 4 & $\begin{array}{c}0.073 \\
(0.084)\end{array}$ & $\begin{array}{c}0.082 \\
(0.082)\end{array}$ & $\begin{array}{c}0.124 \\
(0.085)\end{array}$ & $\begin{array}{c}0.105 \\
(0.085)\end{array}$ & $\begin{array}{c}0.117 \\
(0.082)\end{array}$ & $\begin{array}{c}0.131 \\
(0.083)\end{array}$ \\
\hline \multirow[t]{2}{*}{ Size } & -0.001 & -0.001 & -0.001 & -0.000 & 0.001 & 0.001 \\
\hline & $(0.003)$ & $(0.004)$ & $(0.004)$ & $(0.004)$ & $(0.004)$ & $(0.004)$ \\
\hline \multirow[t]{2}{*}{ Teaching awards } & 0.029 & 0.026 & 0.021 & 0.039 & 0.042 & 0.038 \\
\hline & $(0.066)$ & $(0.068)$ & $(0.065)$ & $(0.068)$ & $(0.070)$ & $(0.068)$ \\
\hline \multirow[t]{2}{*}{ top5-50j } & $0.265 * *$ & $0.259 * *$ & $0.228 * *$ & $0.235 * *$ & $0.243 * *$ & $0.218 * *$ \\
\hline & $(0.105)$ & $(0.105)$ & $(0.105)$ & $(0.106)$ & $(0.100)$ & $(0.098)$ \\
\hline \multirow[t]{2}{*}{ top5-50rr } & 0.139 & 0.161 & 0.140 & 0.100 & 0.124 & 0.133 \\
\hline & $(0.135)$ & $(0.126)$ & $(0.126)$ & $(0.140)$ & $(0.129)$ & $(0.124)$ \\
\hline \multirow[t]{2}{*}{ Topadvisor } & 0.177 & 0.140 & 0.148 & 0.185 & 0.165 & 0.157 \\
\hline & $(0.123)$ & $(0.125)$ & $(0.128)$ & $(0.119)$ & $(0.115)$ & $(0.118)$ \\
\hline Observations & 350 & 350 & 350 & 314 & 314 & 314 \\
\hline Pseudo R-squared & 0.0283 & 0.0592 & 0.122 & 0.0480 & 0.0661 & 0.0777 \\
\hline
\end{tabular}

Robust standard errors in parentheses

*** $\mathrm{p}<0.01,{ }^{* *} \mathrm{p}<0.05,{ }^{*} \mathrm{p}<0.1$ 
Table 8. Tobit Analysis on Job Rank (All Candidates)

\begin{tabular}{|c|c|c|c|c|c|}
\hline VARIABLES & $\begin{array}{c}\text { (1) } \\
\text { Full Sample }\end{array}$ & $\begin{array}{c}\text { (2) } \\
\text { Full Sample } \\
\end{array}$ & $\begin{array}{c}\text { (3) } \\
\text { Full Sample } \\
\end{array}$ & $\begin{array}{c}\text { (4) } \\
\text { Female Only }\end{array}$ & $\begin{array}{c}\text { (5) } \\
\text { Male Only }\end{array}$ \\
\hline Female & $\begin{array}{c}8.704 \\
(28.298)\end{array}$ & $\begin{array}{c}29.502^{* * *} \\
(6.542)\end{array}$ & $\begin{array}{c}17.083 \\
(33.185)\end{array}$ & & \\
\hline U.S. & $\begin{array}{c}32.257 \\
(34.515)\end{array}$ & $\begin{array}{c}31.773 * * * \\
(4.642)\end{array}$ & $\begin{array}{c}32.590 \\
(34.751)\end{array}$ & $\begin{array}{c}57.261 \\
(82.412)\end{array}$ & $\begin{array}{c}21.022 \\
(31.815)\end{array}$ \\
\hline China & $\begin{array}{c}22.148 \\
(41.894)\end{array}$ & $\begin{array}{c}96.775^{* * *} \\
(9.128)\end{array}$ & $\begin{array}{c}22.764 \\
(41.624)\end{array}$ & $\begin{array}{l}-10.041 \\
(49.672)\end{array}$ & $\begin{array}{c}82.291 \\
(63.826)\end{array}$ \\
\hline India & $\begin{array}{l}-47.377 \\
(41.289)\end{array}$ & $\begin{array}{c}-92.105 * * * \\
(10.100)\end{array}$ & $\begin{array}{l}-47.601 \\
(41.554)\end{array}$ & $\begin{array}{c}12.014 \\
(66.238)\end{array}$ & $\begin{array}{l}-96.185^{*} \\
(57.611)\end{array}$ \\
\hline Korea & $\begin{array}{c}166.841^{* * *} \\
(60.868)\end{array}$ & $\begin{array}{c}188.096 * * * \\
(8.542)\end{array}$ & $\begin{array}{c}167.455^{* * *} \\
(60.712)\end{array}$ & $\begin{array}{l}135.180^{*} \\
(75.643)\end{array}$ & $\begin{array}{c}178.083^{* *} \\
(74.595)\end{array}$ \\
\hline Russia & $\begin{array}{c}16.646 \\
(54.567)\end{array}$ & $\begin{array}{c}42.754 * * * \\
(12.426)\end{array}$ & $\begin{array}{c}15.203 \\
(53.824)\end{array}$ & $\begin{array}{c}-55.416 \\
(119.504)\end{array}$ & $\begin{array}{c}30.407 \\
(49.450)\end{array}$ \\
\hline Turkey & $\begin{array}{l}-69.737 \\
(48.864)\end{array}$ & $\begin{array}{c}-155.086^{* * * *} \\
(6.501)\end{array}$ & $\begin{array}{l}-70.030 \\
(48.277)\end{array}$ & $\begin{array}{c}1,427.906 \\
(0.000)\end{array}$ & $\begin{array}{c}-162.910 * * * \\
(41.858)\end{array}$ \\
\hline Japan & $\begin{array}{l}-12.572 \\
(68.464)\end{array}$ & $\begin{array}{c}42.929 * * * \\
(5.851)\end{array}$ & $\begin{array}{l}-14.570 \\
(69.237)\end{array}$ & $\begin{array}{c}-439.821^{* * *} \\
(61.065)\end{array}$ & $\begin{array}{c}30.703 \\
(60.676)\end{array}$ \\
\hline Italy & $\begin{array}{c}127.638 \\
(105.681)\end{array}$ & $\begin{array}{c}1,379.374 * * * \\
(46.814)\end{array}$ & $\begin{array}{c}127.904 \\
(107.391)\end{array}$ & $\begin{array}{c}3.782 \\
(128.384)\end{array}$ & $\begin{array}{c}1,348.202 \\
(0.000)\end{array}$ \\
\hline Taiwan & $\begin{array}{c}29.150 \\
(61.958)\end{array}$ & $\begin{array}{c}2.458 \\
(13.959)\end{array}$ & $\begin{array}{c}25.265 \\
(62.974)\end{array}$ & $\begin{array}{c}79.190 \\
(97.583)\end{array}$ & $\begin{array}{c}-9.458 \\
(91.256)\end{array}$ \\
\hline Argentina & $\begin{array}{l}-46.654 \\
(60.508)\end{array}$ & $\begin{array}{c}-41.137 * * * \\
(5.732)\end{array}$ & $\begin{array}{l}-51.894 \\
(57.306)\end{array}$ & & $\begin{array}{c}-49.672 \\
(60.266)\end{array}$ \\
\hline Female*Italy & & $\begin{array}{c}-1,366.203^{* * *} \\
(46.814)\end{array}$ & & & \\
\hline Female*Taiwan & & $\begin{array}{c}52.041 * * * \\
(19.550)\end{array}$ & & & \\
\hline Female*Japan & & $\begin{array}{c}-488.283^{* * *} \\
(16.362)\end{array}$ & & & \\
\hline Female*China & & $\begin{array}{c}-128.458^{* * * *} \\
(12.800)\end{array}$ & & & \\
\hline Female*India & & $\begin{array}{c}80.043^{* * *} \\
(12.292)\end{array}$ & & & \\
\hline
\end{tabular}




\begin{tabular}{|c|c|c|c|c|c|}
\hline Female*Korea & & $\begin{array}{c}-72.804 * * * \\
(17.397)\end{array}$ & & & \\
\hline Female*Russia & & $\begin{array}{c}-77.030 * * * \\
(16.483)\end{array}$ & & & \\
\hline Female*Turkey & & $\begin{array}{c}1,481.327 \\
(0.000)\end{array}$ & & & \\
\hline Additional master degree & $\begin{array}{c}9.900 \\
(26.401)\end{array}$ & $\begin{array}{l}10.056^{*} \\
(5.875)\end{array}$ & $\begin{array}{c}10.117 \\
(26.223)\end{array}$ & $\begin{array}{c}14.190 \\
(52.630)\end{array}$ & $\begin{array}{c}8.559 \\
(29.846)\end{array}$ \\
\hline Ph.D. tier 2 & $\begin{array}{c}40.794 \\
(27.714)\end{array}$ & $\begin{array}{c}39.747 * * * \\
(3.918)\end{array}$ & $\begin{array}{c}54.672 \\
(33.736)\end{array}$ & $\begin{array}{c}-9.447 \\
(43.091)\end{array}$ & $\begin{array}{l}62.306^{*} \\
(34.843)\end{array}$ \\
\hline Ph.D. tier 3 & $\begin{array}{l}75.729 * * \\
(32.889)\end{array}$ & $\begin{array}{l}65.588 * * * \\
(5.715)\end{array}$ & $\begin{array}{l}75.438 * * \\
(32.750)\end{array}$ & $\begin{array}{c}15.751 \\
(50.665)\end{array}$ & $\begin{array}{l}87.680^{*} \\
(46.929)\end{array}$ \\
\hline Ph.D. tier 4 & $\begin{array}{c}250.914 * * * \\
(42.007)\end{array}$ & $\begin{array}{c}253.526 * * * \\
(4.589)\end{array}$ & $\begin{array}{c}250.431^{* * * *} \\
(41.877)\end{array}$ & $\begin{array}{c}208.535 * * * \\
\quad(65.236)\end{array}$ & $\begin{array}{c}269.271 * * * \\
(55.830)\end{array}$ \\
\hline Size & $\begin{array}{c}2.455 \\
(2.010)\end{array}$ & $\begin{array}{c}2.638 * * * \\
(0.348)\end{array}$ & $\begin{array}{c}2.435 \\
(1.997)\end{array}$ & $\begin{array}{c}0.540 \\
(3.600)\end{array}$ & $\begin{array}{c}3.441 \\
(2.226)\end{array}$ \\
\hline Teaching awards & $\begin{array}{c}3.765 \\
(16.394)\end{array}$ & $\begin{array}{l}5.800 * * \\
(2.607)\end{array}$ & $\begin{array}{c}3.356 \\
(16.549)\end{array}$ & $\begin{array}{c}22.357 \\
(52.313)\end{array}$ & $\begin{array}{c}5.065 \\
(17.729)\end{array}$ \\
\hline top4j & $\begin{array}{c}-160.698 * * * \\
(32.006)\end{array}$ & $\begin{array}{c}-133.473 * * * \\
(7.817)\end{array}$ & $\begin{array}{c}-159.989 * * * \\
(31.384)\end{array}$ & $\begin{array}{c}71.660 \\
(155.175)\end{array}$ & $\begin{array}{c}-194.401 * * * \\
(26.263)\end{array}$ \\
\hline top4rr & $\begin{array}{c}1,563.154 \\
(0.000)\end{array}$ & $\begin{array}{c}1,442.473 \\
(0.000)\end{array}$ & $\begin{array}{c}1,566.313 \\
(0.000)\end{array}$ & $\begin{array}{c}1,345.840 \\
(0.000)\end{array}$ & $\begin{array}{c}1,489.679 \\
(0.000)\end{array}$ \\
\hline top5-50j & $\begin{array}{c}34.417 \\
(47.903)\end{array}$ & $\begin{array}{l}26.836 * * * \\
(5.259)\end{array}$ & $\begin{array}{c}35.495 \\
(48.400)\end{array}$ & $\begin{array}{c}39.317 \\
(120.671)\end{array}$ & $\begin{array}{c}36.717 \\
(50.958)\end{array}$ \\
\hline top5-50rr & $\begin{array}{c}-151.065 * * * \\
(48.772)\end{array}$ & $\begin{array}{c}-132.030 * * * \\
(6.079)\end{array}$ & $\begin{array}{c}-150.473 * * * \\
(49.235)\end{array}$ & $\begin{array}{c}-60.773 \\
(122.268)\end{array}$ & $\begin{array}{c}-145.740 * * * \\
(51.746)\end{array}$ \\
\hline Topadvisor & $\begin{array}{c}-2.018 \\
(52.242)\end{array}$ & $\begin{array}{c}-23.209 * * * \\
(4.010)\end{array}$ & $\begin{array}{c}-2.194 \\
(52.237)\end{array}$ & $\begin{array}{l}-62.631 \\
(70.939)\end{array}$ & $\begin{array}{c}9.253 \\
(69.489)\end{array}$ \\
\hline Female*Program Tier Dummy & $\mathrm{N}$ & $\mathrm{N}$ & $\mathrm{Y}$ & $\mathrm{N}$ & $\mathrm{N}$ \\
\hline Constant & $\begin{array}{c}152.001 * * * \\
(48.601)\end{array}$ & $\begin{array}{c}142.442 * * * \\
(6.826)\end{array}$ & $\begin{array}{c}149.650 * * * \\
(49.993)\end{array}$ & $\begin{array}{c}219.857 * * * \\
(73.417)\end{array}$ & $\begin{array}{c}121.569 * * \\
(54.851)\end{array}$ \\
\hline $\begin{array}{l}\text { Observations } \\
\text { Pseudo R-sauared }\end{array}$ & 511 & 511 & 511 & 175 & 336 \\
\hline Pseudo R-squared & 0.0236 & 0.0304 & 0.0237 & 0.0272 & 0.0338 \\
\hline
\end{tabular}

